\title{
Plasminogen activator inhibitor type 1 regulates microglial motility and phagocytic activity
}

\author{
Hyejin Jeon ${ }^{1}$, Jong-Heon Kim', Jae-Hong Kim', Won-Ha Lee², Myung-Shik Lee ${ }^{3}$ and Kyoungho Suk ${ }^{1 *}$
}

\begin{abstract}
Background: Plasminogen activator inhibitor type 1 (PAI-1) is the primary inhibitor of urokinase type plasminogen activators (UPA) and tissue type plasminogen activators (tPA), which mediate fibrinolysis. PAl-1 is also involved in the innate immunity by regulating cell migration and phagocytosis. However, little is known about the role of PAI-1 in the central nervous system.
\end{abstract}

Methods: In this study, we identified PAl-1 in the culture medium of mouse mixed glial cells by liquid chromatography and tandem mass spectrometry. Secretion of PAl-1 from glial cultures was detected by ELISA and western blotting analysis. Cell migration was evaluated by in vitro scratch-wound healing assay or Boyden chamber assay and an in vivo stab wound injury model. Phagocytic activity was measured by uptake of zymosan particles.

Results: The levels of PAI-1 mRNA and protein expression were increased by lipopolysaccharide and interferon- $\gamma$ stimulation in both microglia and astrocytes. PAl-1 promoted the migration of microglial cells in culture via the low-density lipoprotein receptor-related protein (LRP) 1/Janus kinase (JAK)/signal transducer and activator of transcription (STAT)1 axis. PAl-1 also increased microglial migration in vivo when injected into mouse brain. PAl-1mediated microglial migration was independent of protease inhibition, because an R346A mutant of PAl-1 with impaired PA inhibitory activity also promoted microglial migration. Moreover, PAI-1 was able to modulate microglial phagocytic activity. PAl-1 inhibited microglial engulfment of zymosan particles in a vitronectin- and Toll-like receptor 2/6-dependent manner.

Conclusion: Our results indicate that glia-derived PAl-1 may regulate microglial migration and phagocytosis in an autocrine or paracrine manner. This may have important implications in the regulation of brain microglial activities in health and disease.

\section{Introduction}

Activated glial cells secrete a variety of proteins including proinflammatory cytokines, chemokines, and neurotoxic factors under inflammatory or pathological conditions $[1,2]$. Secretomic analysis has been previously conducted for astrocytes [3-5] and microglia [6,7] to determine the profile of the secreted proteins. Some of these secreted proteins play important roles in the progression of inflammatory diseases in the brain, and serve as biomarkers that can be used to guide diagnosis and drug therapy. Microglia, the resident macrophages of the CNS, constitute the brain's innate immune system and

\footnotetext{
*Correspondence: ksuk@knu.ac.kr

'Department of Pharmacology, Brain Science \& Engineering Institute, CMRI, Kyungpook National University School of Medicine, 101 Dong-In, Daegu, Joong-gu 700-422, South Korea

Full list of author information is available at the end of the article
}

play a pivotal role in neuroinflammation and host defense against microbial agents [8-12]. Microglia, as phagocytes, engulf invaded pathogens, apoptotic cells, and their debris $[11,13]$. Chronically activated microglia also contribute to neurotoxicity in neurodegenerative diseases, such as Alzheimer's disease (AD), Parkinson's disease (PD), amyotrophic lateral sclerosis, Huntington's disease, and multiple sclerosis (MS) [14-19]. Migration of microglia, via extension of their processes, to the site of inflammation is a key step in the progression of the inflammatory brain diseases [20].

Plasminogen activator inhibitor type 1 (PAI-1), also known as serine protease inhibitor E1, is expressed in various cell types such as adipocytes, glomerular mesangial cells, epithelial cells, vascular endothelial cells, vascular smooth-muscle cells, monocytes/macrophages, and astrocytes [21-23]. PAI-1 acts as the main inhibitor of

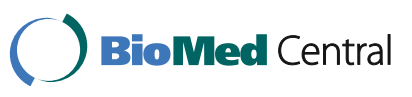


both urokinase type plasminogen activators (uPA) and tissue type plasminogen activators (tPA), which convert plasminogen to plasmin. This plasmin activator/inhibitor system is involved in the regulation of fibrinolysis, and remodeling of the extracellular matrix, cell migration, and invasion of tumor cells [21,24-26]. PAI-1 is also involved in the distinction between viable and apoptotic cells, and PAI-1 regulates the phagocytosis of apoptotic cells [27]. PAI-1 plays a dual role in the regulation of cell migration through differential interactions with its binding partners such as uPA, tPA, vitronectin, and lowdensity lipoprotein receptor-related protein (LRP)1. The PAI-vitronectin complex binds to the Arg-Gly-Asp motif of $\alpha v$ integrins and inhibits the integrin-mediated cell migration [28-33]. The PAI-1/uPA/uPAR complex inhibits uPA-induced cell migration [34], whereas the interaction between PAI-1 and LRP1 stimulates the movement of monocytes [35-37]. The LRP1/tPA/PAI-1 complex induces Mac-1-dependent macrophage migration [37]. Thus, the effect of PAI-1 on cell migration depends on the binding proteins involved, which are expressed in a cell- and tissue-specific manner. Overexpression of PAI-1 has been detected in various brain disorders, such as glioma, ischemic stroke, MS, and AD [18,38-42]. Several reports have indicated an important role of PAI-1 in the CNS injury and pathology. Increased PAI-1 was shown to interfere with the clearance and degradation of amyloid- $\beta$ by blocking tPA, and inactivation of PAI-1 retarded the progression of AD pathology [39]. PAI-1 reduced brain edema and axonal degeneration after ischemic brain injury [42]. PAI-1 produced by astrocytes protected neurons against $\mathrm{N}$-methyl-D-aspartate receptor-mediated excitotoxicity [43], and PAI-1 expressed in olfactory ensheathing glia was shown to promote axonal regeneration [44]. However, the role of PAI-1 in the regulation of microglial functions has not been investigated.

In the present study, we identified PAI-1 as a protein secreted from mixed glial cultures after stimulation with lipopolysaccharide (LPS) and interferon (IFN)- $\gamma$. PAI-1 levels were increased in both microglia and astrocytes by inflammatory stimulation. Subsequent studies showed that glia-derived PAI-1 specifically regulated microglial cell motility. Using LRP1 small interfering (si)RNA and low-density lipoprotein receptor-associated protein (RAP), we found that PAI-1 promoted microglial migration through an LRP1-dependent mechanism. Further examination of the signaling pathways indicated that the PAI-1/LRP1 complex enhanced microglial migration via the JAK/STAT1 pathway. The migration-promoting effect of PAI-1 did not require the PA inhibitory activity, either in vitro or in vivo. In addition, we found that PAI1 inhibits microglial phagocytic activity. Studies using PAI-1 mutant proteins indicated that the inhibitory effect of PAI-1 on microglial phagocytosis was dependent on vitronectin but not LRP1. Taken together, our results suggest that PAI-1 may be released predominantly by microglia and astrocytes under inflammatory conditions of the brain, and the secreted PAI-1 protein may regulate microglial migration and phagocytosis in CNS inflammation.

\section{Methods}

The animals used in this study were maintained under temperature- and humidity-controlled conditions with a 12 hour light/12 hour dark cycle. All animal experiments were approved by the institutional review board of Kyungpook National University School of Medicine and were carried out in accordance with the guidelines in the NIH Guide for the Care and Use of Laboratory Animals.

\section{Reagents}

LPS (from Escherichia coli 0111: B4 prepared by phenolic extraction and gel filtration chromatography), BSA, and rabbit serum were all purchased from Sigma (Sigma, St Louis, MN, USA). Recombinant mouse IFN- $\gamma$, RAP protein, and recombinant human vitronectin protein were purchased from R\&D Systems (Minneapolis, MN, USA). Lipoteichoic acid (LTA) from Bacillus subtilis was purchased from InvivoGen (Carlsbad, CA, USA). 5chloromethyl-fluoresceindiacetate (CMFDA) was purchased from Molecular Probes Inc (Eugene, OR, USA). JAK inhibitor AG490 ((E)-N-benzyl-2-cyano-3-(3,4-dihydroxyphenyl) acrylamide a-cyano-(3,4-dihydroxy)-N-benzylcinnamide tyrphostin B42), was purchased from Calbiochem (La Jolla, CA, USA). Recombinant mouse PAI-1 protein was purchased from American Diagnostica (Greenwich, CT, USA), and was diluted in PBS. All other chemicals, unless otherwise stated, were obtained from Sigma.

\section{Preparation of recombinant human PAI-1 proteins}

The bacterially expressed recombinant human PAI-1 wild-type and mutant proteins (Q123K and R346A) were prepared as previously described [45]. The PAI-1 mutant Q123K was unable to bind to vitronectin $[16,46,47]$, and the R346A mutant was unable to inhibit PA [28,45]. In brief, the coding region of recombinant wild-type human PAI-1 (amino acids 24-402, Swiss-Prot primary accession number P22777) was cloned into the PRSET B vector with an N-terminal polyhistidine $(6 \times$ His) tag (kindly provided by Dr Hana Im, Sejong University, Seoul, Korea) [47]. This PAI-1 construct lacks the N-terminal secretory signal region. Human PAI-1 mutants were generated by using a site-directed mutagenesis kit (QuikChange; Stratagene, La Jolla, CA, USA) in accordance with the manufacturer's instructions. The pRSET B vector containing the wild-type or mutant PAI-1 cDNA was 
transformed into the competent $E$. coli strain BL21(DE3) pLysS, which was then grown at $37^{\circ} \mathrm{C}$ in $500 \mathrm{ml}$ of Luria broth medium supplemented with $100 \mu \mathrm{g} / \mathrm{ml}$ ampicillin. The expression of recombinant proteins was induced with $0.1 \mathrm{mmol} / \mathrm{l}$ Isopropyl $\beta$-D-1-thiogalactopyranoside (IPTG) for 3 hours, and then cells were lysed by sonication. The protein was purified by using nickel-nitrilotriacetic acid (Ni-NTA) beads (Qiagen, Chatsworth, CA, USA) in accordance with the manufacturer's instructions. Ni-NTA-bound proteins were then eluted with an buffer containing $50 \mathrm{mmol} / \mathrm{l}$ Tris-HCl (pH 8.0), $100 \mathrm{mmol} / \mathrm{l} \mathrm{NaCl}$, and $200 \mathrm{mmol} / \mathrm{l}$ imidazole. The purified protein was dialyzed (Slide-A-Lyzer Dialysis Cassettes; Pierce, Rockford, IL, USA), and then concentrated using centrifugal dialysis filtration tubes (Millipore, Billerica, MA, USA).

\section{Cell cultures}

The BV-2 mouse microglial cell line, which exhibits phenotypic and functional properties comparable with those of primary microglial cells $[48,49]$, was grown and maintained in DMEM containing 5\% FBS, $2 \mathrm{mmol} / \mathrm{l}$ glutamine, penicillin, and streptomycin (Gibco, Gaithersburg, MD, USA) at $37^{\circ} \mathrm{C}$ in $95 \%$ air $/ 5 \% \mathrm{CO}_{2}$. C6 rat glioma cells were grown and maintained under the same condition as the BV-2 microglial cells. Primary mixed glial cells and astrocyte cultures were prepared as previously described [50]. In brief, the forebrains of newborn ICR mice were chopped and dissociated by mechanical disruption using a nylon mesh.

The cells were seeded into culture flasks. Mixed glial cultures were established after in vitro culture for 10 to 14 days at $37^{\circ} \mathrm{C}$ in $95 \%$ air $/ 5 \% \mathrm{CO}_{2}$. Mixed glial cultures were composed of $61.86 \pm 1.44 \%$ astrocytes, $28.73 \pm 2.23 \%$ microglia, and $9.36 \pm 1.92 \%$ 'other cell types' as determined by glial fibrillary acidic protein (GFAP) and ionized calcium binding adaptor molecule 1 (Iba-1) staining [51]. Astrocytes were isolated from mixed glial cultures by shaking at $270 \mathrm{rpm}$ for 2 hours. This resulted in the detachment of microglia, whereas astrocytes remained attached to the bottom of the culture flask. The detached microglia were aspirated, and the remaining astrocytes were used for experiments. Astrocyte cultures were composed of $92.56 \pm 3.14 \%$ astrocytes, $0.45 \pm 1.0 \%$ microglia, and $6.99 \pm 2.23 \%$ other cell types as determined by GFAP and Iba-1 staining.

Primary microglial cultures were separately prepared by mild trypsinization as previously described [52] with minor modifications. After in vitro culture for 10 to 14 days, microglial cells were isolated from mixed glial cultures by mild trypsinization. Mixed glial cultures were incubated with a trypsin solution (0.25\% trypsin, $1 \mathrm{mmol} / \mathrm{l}$ EDTA in Hank's balanced salt solution) diluted 1:4 in PBS containing $1 \mathrm{mmol} / \mathrm{l} \mathrm{CaCl}_{2}$ for 30 to $60 \mathrm{~min}$ utes. This resulted in the detachment of the upper layer of astrocytes in one piece, whereas microglia remained attached to the bottom of the culture flask. The detached layer of astrocytes was aspirated, and the remaining microglia were used for experiments. The purity of microglial cultures was greater than $95 \%$ as determined by GFAP and Iba-1 staining. Primary glial cultures were grown and maintained in DMEM supplemented with $10 \%$ FBS, $100 \mathrm{U} / \mathrm{ml}$ of penicillin, and $100 \mu \mathrm{g} / \mathrm{ml}$ of streptomycin.

Primary cultures of dissociated cerebral cortical neurons were prepared as previously described [53]. Cortical neurons were grown in neurobasal medium containing $10 \% \mathrm{FBS}, 0.5 \mathrm{mmol} / \mathrm{l}$ glutamine, $100 \mathrm{U} / \mathrm{ml}$ of penicillin, $100 \mu \mathrm{g} / \mathrm{ml}$ of streptomycin, N2 supplement (Gibco), and B27 supplement (Gibco). The purity of the neuronal cultures was determined by immunocytochemical staining, using an antibody against a neuron-specific marker, microtubule-associated protein 2 (Promega, Madison, WI, USA).

\section{Proteomic analysis of conditioned medium of mixed glial cultures}

Conditioned medium from mixed glial cultures or cell extracts was prepared as previously described [51]. Cells were treated with a combination of LPS $(100 \mathrm{ng} / \mathrm{ml})$ and IFN- $\gamma(50 \mathrm{U} / \mathrm{ml})$ at $37^{\circ} \mathrm{C}$ in $95 \%$ air $/ 5 \% \mathrm{CO}_{2}$ for 24 hours. The stimulation was performed under serum-free conditions. Precipitated proteins were analyzed by liquid chromatography and tandem mass spectrometry (LCMS/MS) as previously described [51,54].

\section{Traditional reverse transcriptase PCR and real-time PCR}

Total RNA was extracted from cells by using TRIzol reagent (Invitrogen), in accordance with the manufacturer's protocol. Reverse transcription was conducted using reverse transcriptase (Superscript II; Invitrogen) and oligo(dT) primers. PCR amplification, using specific primer sets, was carried out at an annealing temperature of 55 to $60^{\circ} \mathrm{C}$ for $25-30$ cycles. The PCR was performed in a thermal cycler (DNA Engine Tetrad Peltier; MJ Research, Waltham, MA, USA). For the analysis of PCR products, $10 \mu \mathrm{l}$ of each PCR was separated by electrophoresis in 1\% agarose gels and viewed under UV light. $\beta$-actin was used as an internal control. Nucleotide sequences of the primers were based on published cDNA sequences of mouse LRP-1, PAI-1, Toll-like receptor (TLR)2, TLR6, dectin-1, and $\beta$-actin (Table 1)

Real-time PCR was performed using a commercial kit (One Step SYBR ${ }^{\circledR}$ PrimeScript ${ }^{\mathrm{TM}}$; Takara Bio Inc, Japan) in accordance with the manufacturer's instructions, followed by detection using the ABI Prism ${ }^{\circledR} 7000$ Sequence Detection System (Applied Biosystems, Foster City, CA). Nucleotide sequences of the primers were based on 
Table 1 List of PCR primers used in the study

\begin{tabular}{|c|c|c|}
\hline Name & Accession number & Forward primer $\left(5^{\prime} \rightarrow 3^{\prime}\right)$ \\
\hline \multicolumn{3}{|c|}{ Reverse transcriptase PCR } \\
\hline \multirow[t]{2}{*}{ LRP1 } & NM_008512 & Forward GCGTGGGTGTGTGATGGCGA \\
\hline & & Reverse GTTGCGCAGGCCAGGCACTA \\
\hline \multirow[t]{2}{*}{ PAl-1 } & NM_008871 & Forward GTCTITCCGACCAAGAGCAG \\
\hline & & Reverse GCCGAACCACAAAGAGAAAG \\
\hline \multirow[t]{2}{*}{ TLR2 } & NM_011905.3 & Forward ACAGCTACCTGTGTGACTCTCCGCC \\
\hline & & Reverse GGTCTTGGTGTTCATTATCTTGCGC \\
\hline \multirow[t]{2}{*}{ TLR6 } & NM_011604.3 & Forward CTGCCCTGGTATGTGAGGAT \\
\hline & & Reverse TCTGGATGAAGTGGGGAGAC \\
\hline \multirow[t]{2}{*}{ Dectin-1 } & AY534909.1 & Forward GACTTCAGCACTCAAGACATCC \\
\hline & & Reverse TTGTGTCGCCAAAATGCTAGG \\
\hline \multirow[t]{2}{*}{$\beta$-actin } & NM_007393.3 & Forward ATCCGTAAAGACCTCTATGC \\
\hline & & Reverse AACGCAGCTCAGTAACAGTC \\
\hline
\end{tabular}

Real-time PCR

PAI-1 NM_008871

Forward CATGCCCCACTTCTTCAAGCT

Reverse TGGTATGCCTTTCCACCCAGT

GAPDH NM_008084.2

Forward TGGGCTACACTGAGCACCAG

Reverse GGGTGTCGCTGTTGAAGTCA

LRP, Low-density lipoprotein receptor-related protein; PAl, plasminogen activator inhibitor; TLR, Toll-like receptor.

published cDNA sequences of mouse PAI-1 and mouse GAPDH (Table 1), the latter used as an internal control.

\section{Western blotting analysis}

Western blotting analysis was carried out as previously described [51]. In brief, cells were treated with LPS (100 ng/ml), IFN- $\gamma(50 \mathrm{U} / \mathrm{ml})$, or mouse PAI-1 $(100 \mathrm{ng} / \mathrm{ml})$ at $37^{\circ} \mathrm{C}$ in $95 \%$ air $/ 5 \% \mathrm{CO}_{2}$. Cells were washed with $\mathrm{PBS}$ and lysed in triple-detergent lysis buffer $(50 \mathrm{mmol} / \mathrm{l}$ Tris$\mathrm{HCl}(\mathrm{pH} 8.0), 150 \mathrm{mmol} / \mathrm{l} \mathrm{NaCl}, 0.02 \%$ sodium azide, and $1 \%$ NP-40). After SDS-PAGE separation of the cell lysates, proteins were transferred to nitrocellulose membranes (Amersham Biosciences, Piscataway, NJ, USA). The membranes were blocked with 5\% skim milk, and sequentially incubated with primary antibodies (rabbit polyclonal antimouse PAI-1 antibody, anti-LRP1 antibody (H-80; raised against the N-terminal extracellular domain of $515 \mathrm{kDa}$ LRP1) (both Santa Cruz Biotechnology, Santa Cruz, CA, USA), rabbit polyclonal anti-STAT1 antibody, rabbit polyclonal anti-phospho-STAT1 antibody (both Cell Signaling Technology, Beverly, MA, USA), monoclonal anti-mouse TLR2 antibody, monoclonal anti-mouse TLR6 antibody monoclonal anti-mouse TLR9 antibody (all Imgenex, San Diego, CA, USA), or monoclonal anti- $\alpha$-tubulin clone B-51-2 mouse ascites fluid (Sigma)), and horseradish peroxidase (HRP)-conjugated secondary antibodies (anti-mouse IgG (Amersham Biosciences) and anti-rabbit IgG (Cell
Signaling Technology)), followed by ECL detection (Amersham Biosciences).

\section{Indirect ELISA for plasminogen activator inhibitor type 1} Indirect ELISA was used for the recombinant mouse PAI-1 protein measurements. Cells were treated with a combination of LPS $(100 \mathrm{ng} / \mathrm{ml})$ and IFN- $\gamma(50 \mathrm{U} / \mathrm{ml})$ for 24 hours. The stimulation was performed under serum-free conditions. The conditioned medium was then collected, and separated by centrifugation at $400 \mathrm{~g}$ for 5 minutes to remove cell debris. The wells of microtiter plates were coated with conditioned medium overnight (diluted 1:1 in $50 \mathrm{mmol} / \mathrm{l}$ carbonate buffer, $\mathrm{pH}$ 9.6; $100 \mu \mathrm{l} /$ well in triplicate wells). Plates were washed with PBS plus $0.1 \%$ Triton X-100 and blocked with PBS plus $5 \%$ BSA for 1 hour. Plates were emptied, and any remaining liquid was tapped out onto dry paper towels. Rabbit polyclonal anti-mouse PAI-1 antibody was added $(1 \mu \mathrm{g} / \mathrm{ml} ; 100 \mu \mathrm{l}$ per well) and incubated for 5 hours. Plates were washed three times with PBS-T to remove unbound antibody. Horseradish peroxidase-labeled antirabbit IgG was added (1:1000 dilution; $100 \mu \mathrm{l}$ per well) and incubated for 1 hour. Plates were washed three times with PBS-T and developed by the addition of $100 \mu \mathrm{l}$ of tetramethylbenzidene peroxide-based substrate solution (R\&D Systems). The recombinant mouse PAI-1 protein was used as a standard.

\section{Nitrite quantification}

Cells were seeded at the density of $5 \times 10^{4}$ cells/well in 96well plates, and treated with various stimuli for 24 hours in serum-free medium. Production of NO was estimated by measuring the amount of nitrite, a stable metabolite of NO, using Griess reagent, as previously described [51].

\section{Assessment of cell viability and proliferation}

Cells $\left(5 \times 10^{4}\right.$ cells in $100 \mu \mathrm{l} /$ well for cell viability assay; $5 \times 10^{3}$ cells in $100 \mu \mathrm{l} /$ well for cell proliferation assay) were seeded in 96-well plates and treated with various stimuli for the specific time periods in the serum-free medium. After treatment, 3-[4,5-dimethylthiazol-2-yl]2,5-diphenyltetrazolium bromide (MTT) assay was performed as previously described [51].

\section{Microglia/neuron co-culture}

For the co-culture of microglia and neurons, primary microglia were seeded at a density of $4 \times 10^{4}$ cells/well in 96 -well plates at $37^{\circ} \mathrm{C}$ in $95 \%$ air $/ 5 \% \mathrm{CO}_{2}$. After 16 hours of incubation, the cells were treated with LPS $(100 \mathrm{ng} / \mathrm{ml})$ and mouse PAI-1 protein $(100 \mathrm{ng} / \mathrm{ml})$ for 12 hours. Culture medium was then removed, and cells were washed with PBS. CMFDA-labeled mouse primary cortical neurons $\left(4 \times 10^{4}\right.$ cells/well $)$ were added to microglia-plated wells and incubated in neurobasal 
medium containing 10\% FBS. After an additional 24 hours incubation period, the number of CMFDA-labeled cells was counted at $\times 100$ magnification in four visual fields in each well using a fluorescence microscope (CK2; Olympus, Tokyo, Japan). Images of five random fields per well were captured and analyzed by an imaging system (MetaMorph; Universal Imaging Corp, West Chester, PA) [53].

\section{Cell migration assays in vitro}

Cell migration was determined by using an in vitro scratch-wound healing assay or Boyden chamber assay. The scratch-wound healing assay was performed as previously described $[55,56]$. In brief, BV-2 mouse microglial cells and C6 rat glioma cells were seeded at a density of $8 \times 10^{4}$ cells/well in 96-well plates, and incubated at $37^{\circ} \mathrm{C}$ under in $95 \%$ air $/ \mathrm{CO}_{2}$ for 14 hours. A scratch wound was created with a $200 \mu$ l pipette tip on the confluent cell monolayer. Cells were treated with or without pharmacological inhibitors, PAI-1 protein, BSA, RAP protein, astrocyte-conditioned medium (ACM), anti-PAI-1 antibody, or rabbit serum. Cells were allowed to recover for 24 hours in serum-free medium. The wound closure was then viewed under a microscope (Olympus CK2; original magnification, $\times 150$ ). Relative cell migration distance was determined by measuring the wound width and subtracting this from the initial value:

fold increase of migration distance $=$ (sample initial wound width at time 0 minus sample wound width at 24 hours of measurement)/(control initial wound width at time 0 minus control wound width at 24 hours of measurement).

A total of three areas were selected and examined in each well. The fold increase of migration distance was based on the average wound width in three areas (an area with maximum width, an area with minimum width, and a randomly chosen area). The results were presented as the fold increase of the migration distance compared with control.

A 48-well Boyden chamber (NeuroProbe, Gaithersburg, MD, USA) was also used for the measurement of cell migration, in accordance with the manufacturer's instructions. The recombinant mouse PAI-1 protein in DMEM containing 10\% FBS was placed into the lower wells, which were separated from the upper wells by polyvinylpyrrolidone-free polycarbonate filters $(8 \mu \mathrm{m}$ pore size, $25 \times 80 \mathrm{~mm}$; NeuroProbe). Primary microglial cells were harvested by trypsinization, resuspended in serum-free DMEM, and added to the upper chamber at a density of $5 \times 10^{4}$ cells/well. Cells were incubated at $37^{\circ} \mathrm{C}$ under in $95 \%$ air $/ 5 \% \mathrm{CO}_{2}$ for 24 hours. At the end of the incubation, any non-migrating cells on the upper side of the membrane were removed with a cotton swab. Migrated cells on the lower part of the membrane were fixed in methanol for 10 minutes and stained with Mayer's hematoxylin (Dako Cytomation, Glostrup, Denmark) for 20 minutes. Photomicrographs of five randomly chosen fields were taken (Olympus CK2) (original magnification, $\times 100$ ), and cells were enumerated to calculate the average number of cells that had migrated. All migrated cells were counted (MetaMorph imaging system; Molecular Devices). Results are presented as the mean \pm SD of triplicates.

\section{Small interfering RNA transfection}

Control siRNA and mouse LRP1 siRNA pool (CGCU GACCCUAUUUGAAGAtt, UCUUCAAAUAGGGUCAG CGtt; CCUUCAGCAUCGAUGUGUUtt,AACACAUCGA UGCUGAAGGtt; CUACCUACAAGAUGUAUGAtt, UC AUACAUCUUGUAGGUAGtt)were purchased from Santa Cruz Biotechnology. siRNA transfection of BV-2 microglial cells was performed (Lipofectamine ${ }^{\mathrm{TM}}$ 2000; Invitrogen) in accordance with the manufacturer's instructions. The cells were harvested 48 hours after transfection, and used for the experiments.

\section{Dot blotting analysis}

Cells were treated with LPS (100 ng/ml), IFN- $\gamma$ (50 U/ $\mathrm{ml})$, or mouse PAI-1 protein $(100 \mathrm{ng} / \mathrm{ml})$. Cells were then washed with PBS and lysed in triple-detergent lysis buffer $(50 \mathrm{mmol} / \mathrm{l}$ Tris- $\mathrm{HCl}(\mathrm{pH} 8.0), 150 \mathrm{mmol} / \mathrm{l} \mathrm{NaCl}$, $0.02 \%$ sodium azide, $1 \% \mathrm{NP}-40$ ). Cell lysates were spotted slowly onto nitrocellulose membranes (Hybond ECL; Amersham Biosciences). The membranes were then blocked with $5 \%$ skim milk and sequentially incubated with anti-LRP1 antibody and HRP-conjugated antirabbit IgG followed by ECL detection.

\section{Astrocyte-conditioned medium}

To prepare ACM, primary astrocyte cultures were seeded at the density of $1.5 \times 10^{6}$ cells in $100 \mathrm{~mm}$ culture dishes. Primary astrocyte cultures were treated with a combination of LPS $(100 \mathrm{ng} / \mathrm{ml})$ and IFN- $\gamma(50 \mathrm{U} / \mathrm{ml})$ for 12 hours. Cells were then washed twice with PBS, and cultured in fresh DMEM for an additional 24 hours. The ACM was then collected, separated by centrifugation at $400 \mathrm{~g}$ for 5 minutes to remove cell debris, and stored at $-80^{\circ} \mathrm{C}$ until further analysis.

\section{Intrastriatal injection of human plasminogen activator inhibitor type 1 (PAI-1) protein}

Mice (body weight $30 \mathrm{~g}$ ) were anesthetized by intraperitoneal injection of tiletamine/zolazepam (30 mg/kg (Zoletil; Virbac Laboratories, Carros, France)) and xylazine (10 mg/kg (Ropum; Bayer, Puteaux, France)), and positioned in a stereotaxic apparatus (Stoelting, Wood Dale, IL, USA). The mice were placed on a homeothermic heat blanket (Harvard Apparatus Co., South Natick, MA, 
USA) at $37^{\circ} \mathrm{C}$ to maintain normal body temperature during surgery. The skull was exposed by a skin incision, and a small hole was drilled through the skull. To avoid passing through the ventricles, the guide cannula was implanted at the stereotaxic coordinates of $1 \mathrm{~mm}$ anterior to the bregma, $2 \mathrm{~mm}$ lateral to the bregma, and $4 \mathrm{~mm}$ below the skull using a $22 \mathrm{G}$ needle, and cemented. Intrastriatal injection of the vehicle (dialyzed elution buffer) or recombinant human PAI-1 protein of wild-type or R346A mutant $(1 \mu \mathrm{l} ; 1.5 \mu \mathrm{g} / \mu \mathrm{l})$ was performed using a $26 \mathrm{G}$ needle. Denatured PAI-I protein, which was used as a control, was prepared by heating for 15 minutes at $95^{\circ} \mathrm{C}$. The flow rate of the injection was $0.1 \mu \mathrm{l} / \mathrm{min}$ maintained by a microsyringe pump (Harvard Apparatus Co.). After removing the needle, the skin was sutured with $6.0 \mathrm{~mm}$ silk thread. The mice were killed 48 hours after the injection.

\section{Immunohistochemistry}

Mice were anesthetized with ether, and transcardially perfused with 4\% paraformaldehyde in PBS. Brains were post-fixed and cryoprotected with $30 \%$ sucrose solution for 24 hours. The fixed brains were embedded in optimal cutting temperature compound (Tissue-Tek; Sakura Fine-Tek, Tokyo Japan) and then cut into $12 \mu \mathrm{m}$-thick coronal sections on a cryostat. The tissues were permeabilized in $0.1 \%$ Triton X-100, and blocked with 1\% BSA and 5\% normal serum. After washing with PBS, the sections were incubated at $4^{\circ} \mathrm{C}$ overnight with rabbit polyclonal Iba-1 antibody (1:500 dilution; Wako, Tokyo, Japan). The sections were then incubated with biotinylated anti-rabbit IgG antibody (1:200 dilution; Vector Laboratories, Burlingame, CA, USA). Subsequently, the sections were incubated with avidin-biotin complex reagents (Vector Laboratories) for 30 minutes at room temperature, followed by detection with diaminobenzidine.

\section{Stab-injury and cell-injection assay}

To evaluate in vivo microglial cell migration, we used a stab-wound injury model as described previously $[57,58]$. ICR mice $(30 \mathrm{~g})$ were anesthetized by intraperitoneal injection of tiletamine/zolazepam $30 \mathrm{mg} / \mathrm{kg}$ and xylazine $10 \mathrm{mg} / \mathrm{kg}$, and positioned in a stereotaxic apparatus, on a homeothermic heat blanket at $37^{\circ} \mathrm{C}$ to maintain normal body temperature during surgery. The skull was exposed by a sagittal skin incision, and a small hole was drilled through the skull. The guide cannula was implanted at $4 \mathrm{~mm}$ lateral from the bregma, and $3 \mathrm{~mm}$ below the skull using a 22 G needle, and cemented. After 3 days, the skull bone located at $2 \mathrm{~mm}$ posterior from the guide cannula was thinned with a high-speed drill, and then a $3 \times 2.5 \times 0.1 \mathrm{~mm}$ sterilized razor blade was stereotaxically inserted to a depth of $3 \mathrm{~mm}$ below the skull to create a coronal stab injury, and immediately removed. After removing the blade, the bone was covered (Bone Wax; Ethicon Inc, Somerville, NJ, USA). Primary microglial cells $\left(7.0 \times 10^{5}\right.$ cells) were incubated with $1 \mu \mathrm{g} / \mathrm{ml}$ of recombinant human PAI-1 proteins (denatured PAI-1 wild-type as a control, wild-type PAI-1, and PAI-1 mutant R346A) in sixwell plates for 12 hours, and labeled with $5 \mu \mathrm{mol} / \mathrm{l}$ CMFDA for 15 minutes. Intracortical cell injection (together with $1 \mu \mathrm{l} \mathrm{PAI}-1$ proteins at $1 \mu \mathrm{g} / \mu \mathrm{l}$ ) was performed using a $26 \mathrm{G}$ needle through a guide cannula with a flow rate of $0.1 \mu \mathrm{l} / \mathrm{min}$ using a microsyringe pump. After surgery, skin was sutured with $6.0 \mathrm{~mm}$ silk thread. At 72 hours after the injection, the mice were killed.

Migration of CMFDA-labeled microglial cells was estimated using immunofluorescence assay. Iba-1 immunofluorescence staining was performed as described above for immunohistochemistry, except the secondary antibody was donkey Cy3-conjugated anti-rabbit antibody (1:1000 dilution; Jackson Immunoresearch Laboratories, West Grove, PA, USA). The sections were mounted on gelatincoated slides and allowed to air-dry overnight.

\section{Data acquisition and immunohistological intensity measurement}

The level of coronal sections that passed the striatum was determined in accordance with a mouse brain atlas. Tiled images of each section were captured with a chargecoupled device color video camera (D70; Olympus) through a $100 \times$ objective lens attached to a microscope (BX51; Olympus). A composite of the images $(640 \times 480$ pixels each; 1 pixel $=2.5 \times 2.5 \mu \mathrm{m})$ was then constructed for each section with Photoshop CS3. Immunohistological intensity analysis of Iba-1 staining was performed (Image J; $\mathrm{NIH}$, Bethesda, MD, USA) as previously described [59]. Composite images of stained sections were fast Fourier transform band-pass filtered to eliminate low-frequency drifts $(>20$ pixels $=50 \mu \mathrm{m})$ and high-frequency noises $(<1$ pixel $=2.5 \mu \mathrm{m})$. The image was set with a binary threshold of $50 \%$ of the background level, and then the particles were converted to a subthreshold image area with a size of 20 to 300 pixels, which was judged as showing the Iba-1positive cells. This range (20 to 300 pixels) was obtained from the analyzed size of Iba-1-positive cells from six sections for each animal. To count the Iba-1 positive cells, five squares $(300 \times 300 \mu \mathrm{m})$ were placed around the injection site in the subthreshold image of the six independent sections, and the cells in the five squares were counted and statistically analyzed.

\section{Phagocytosis of fluorescent zymosan particles}

BV-2 microglial cells were seeded at a density of $7.5 \times 10^{4}$ cells/well in 24-well plates. Cells were treated with the recombinant human PAI-1 protein $(100 \mathrm{ng} / \mathrm{ml})$, mouse PAI- 1 protein (0.1 to $1 \mu \mathrm{g} / \mathrm{ml})$, BSA (2.2 or 
$22.0 \mathrm{nmol} / \mathrm{l})$, monoclonal anti-mouse TLR2 antibody, polyclonal anti-mouse integrin $\beta 3$ (ITGB3) antibody (Cell Signaling Technology), and vitronectin $(1 \mu \mathrm{g} / \mathrm{ml})$ for 1 hour in serum-free DMEM. Cells were then incubated at $37^{\circ} \mathrm{C}$ for 3 hours with $30 \mu \mathrm{g} / \mathrm{ml}$ of fluorescent zymosan particles (zymosan A (Saccharomyces cerevisiae) BioParticles conjugated with Alexa Fluor 594; Molecular Probes Inc). Primary microglia cultures were similarly treated with mouse PAI-1 $(100 \mathrm{ng} / \mathrm{ml})$ or RAP $(5 \mu \mathrm{g} / \mathrm{ml})$ for 1 hour, and then incubated with $30 \mu \mathrm{g} / \mathrm{ml}$ of zymosan particles for 90 minutes. Cells were then washed five times with ice-cold PBS to remove bound particles. Photomicrographs of five randomly chosen fields were taken (CK2; Olympus) in three separate experiments. A minimum of 400 microglial cells per well were counted, and the percentage of phagocytic cells was determined as previously described [51]. Recent reports have indicated that washing three to five times with ice-cold PBS effectively removed extracellular bacteria [60] and zymosan particles $[61,62]$. We also determined by confocal microscopy whether bound particles could be removed by washing five times with ice-cold PBS. After phagocytosis assay, microglial cells with different focal planes were examined under a confocal microscope to visualize the uptake of fluorescent particles. The results indicated that repeated washes could remove surface-bound particles efficiently (data not shown).

\section{Statistical analysis}

All data are presented as mean \pm SD from three or more independent experiments, unless stated otherwise. Statistical comparisons between different treatments were performed by a Student's $t$-test or one-way ANOVA with Dunnett's multiple comparisons by using SPSS software (version 18.0; SPSS Inc, Chicago, IL). $P<0.05$ was considered significant.

\section{Results}

Increase in plasminogen activator inhibitor type 1 (PAI-1) level in both microglia and astrocytes by inflammatory stimuli

Secreted proteins can regulate various cellular processes, such as cell growth, proliferation, cell death/survival, and homeostasis [63,64]. A large-scale analysis of gliaderived proteins may broaden the understanding of glial functions in the CNS $[3,6,51]$. We and others have previously investigated the secretome of brain glial cells $[3,4,6,7,51,65,66]$. Proteins secreted from glial cells have
A
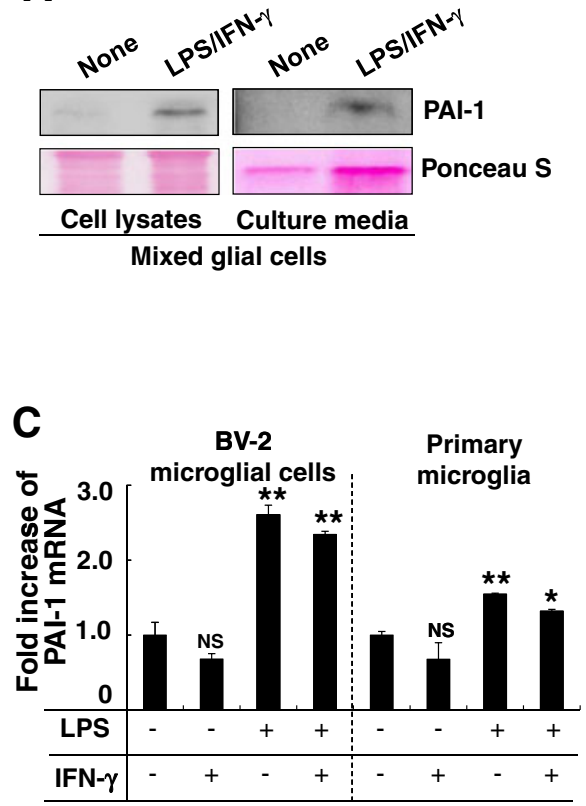

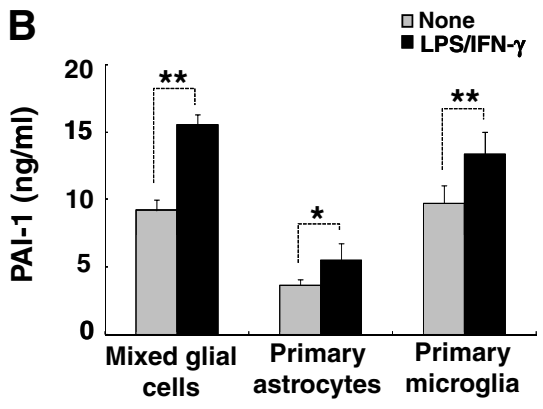

D

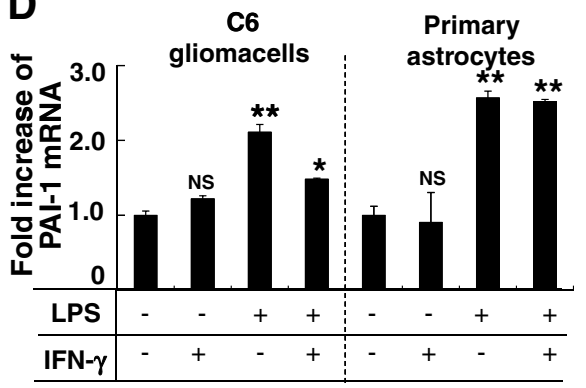

Figure 1 Expression of plasminogen activator inhibitor type 1 (PAI-1) mRNA and protein in mixed glial cultures. (A) Cell lysates or conditioned medium were prepared from either untreated or lipopolysaccharide (LPS)/interferon (IFN)- $\gamma$-treated mixed glial cultures (24 hours treatment). Western blotting analysis was conducted to evaluate the expression level of the $47 \mathrm{kDa}$ PAl- 1 protein. Ponceau $\mathrm{S}$ staining images are shown for comparison. (B) The mixed glial cells, microglia, and astrocytes were stimulated with a combination of LPS (100 ng/ml) and IFN- $\gamma$ (50 $\mathrm{U} / \mathrm{ml}$ ) for 24 hours, and conditioned medium were collected. PA1-1 secretion was measured by ELISA. Results are given as mean \pm SD ( $n=3$ ). ${ }^{*} P<0.05$, ** $P<0.01$. (C, D) Real-time PCR was performed to detect PAl-1 mRNA expression in glial cells treated for 6 hours with LPS (100 ng/ml) and IFN- $\gamma(50 \mathrm{U} / \mathrm{ml})$ either alone or in combination as indicated. GAPDH was used as an internal control. Results are given as mean \pm SD $(n=3)$. ${ }^{*} P<0.05,{ }^{* *} P<0.01, \mathrm{NS}=$ not significant; compared with the untreated control cells. 
been shown to regulate neuron-glia communication and to play important roles in interglial interactions [67]. In the present study, we identified PAI-1 as the major secreted protein of glia through LC-MS/MS analysis of mouse mixed glial cultures. Primary mixed glial cultures were prepared from neonatal mouse brain and treated with LPS and IFN- $\gamma$ for 24 hours. Conditioned medium was then subjected to LC-MS/MS analysis. PAI-1 secretion was strongly induced by LPS/IFN- $\gamma$ treatment in the mixed glial cultures, with the number of peptide hits in unstimulated and LPS/IFN- $\gamma$-stimulated glia being 0 and 16 , respectively.

PAI-1 secretion from mixed glial cells was verified by western blotting analysis using a specific antibody. The PAI-1 protein band of $47 \mathrm{kDa}$ was detected in cell lysates and conditioned medium. LPS/IFN- $\gamma$ increased PAI-1 protein expression was 4.63-fold in the glial lysates and 6.23fold in the conditioned medium, respectively, when

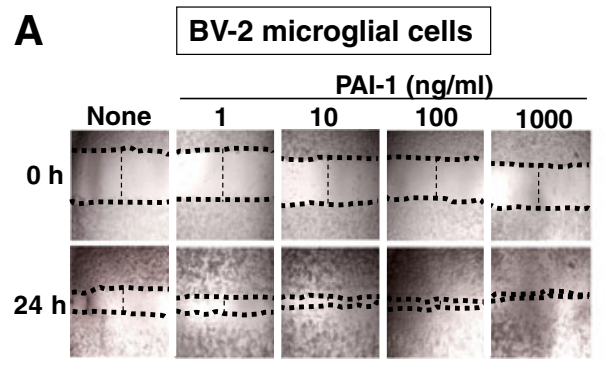

\section{B BV-2 microglial cells}
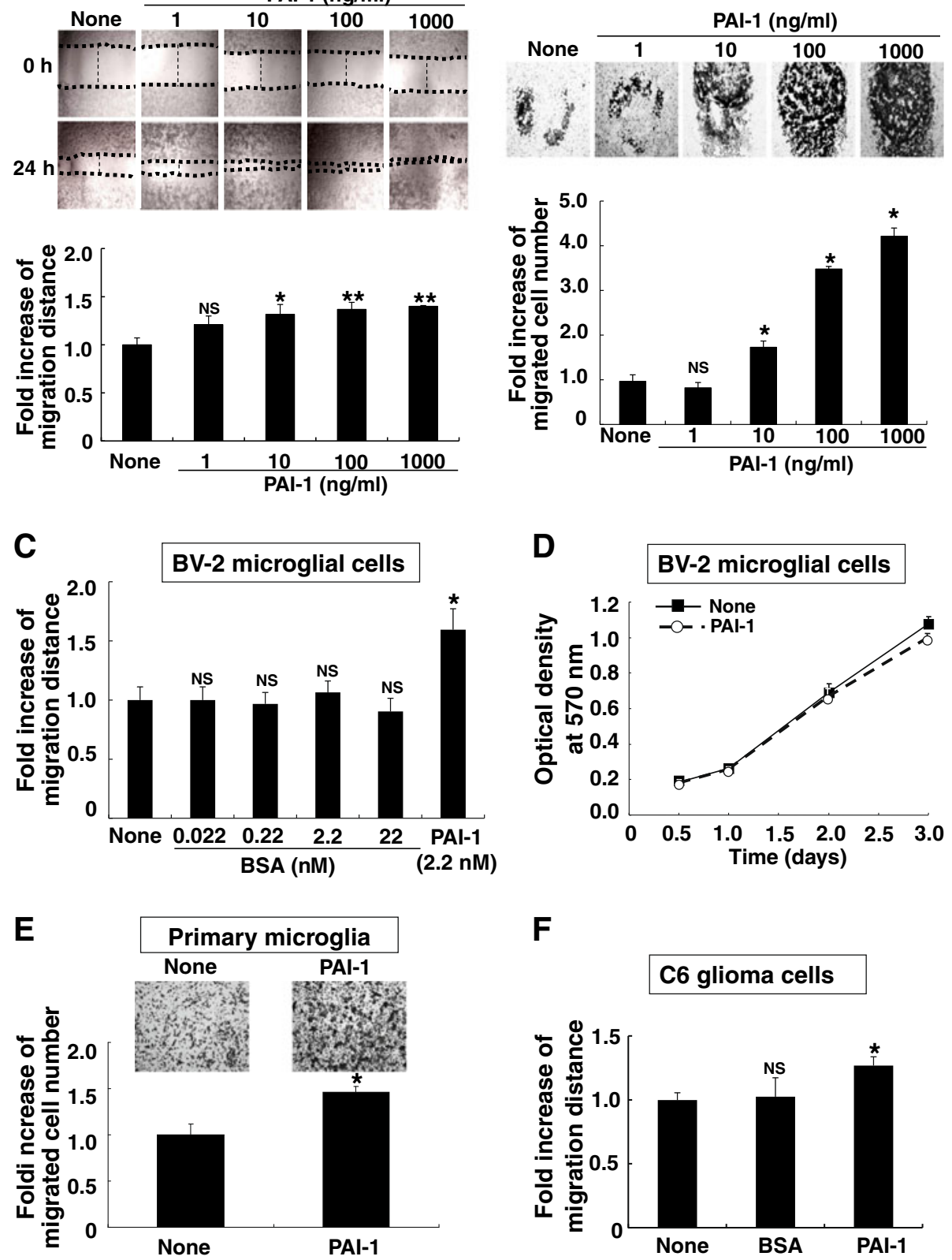

$\mathbf{F}$

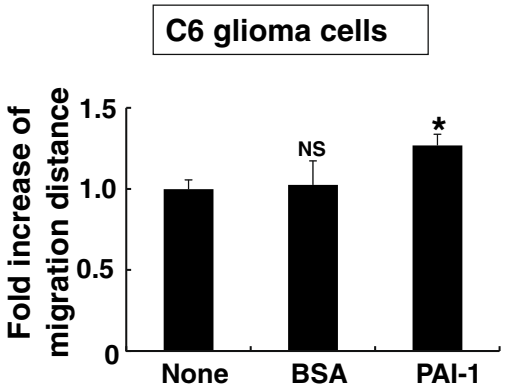

Figure $\mathbf{2}$ (See legend on next page.) 
(See figure on previous page.)

Figure 2 Plasminogen activator inhibitor type 1 (PAI-1) promoted the migration of microglia in a concentration-dependent manner. (A) BV-2 microglial cells were seeded at a density of $8.0 \times 10^{4}$ cells/well in 96 -well plates. When the BV-2 microglial cells had reached 80 to $90 \%$ confluence, a single scratch wound was made by using a $200 \mu$ pipette tip, and the cell debris was removed by washing with PBS. Cells were treated with mouse PAl-1 protein $(0$ to $1000 \mathrm{ng} / \mathrm{ml})$. At 0 and 24 hours, phase-contrast pictures of the wounds at three different locations were taken, and then the fold increase of migration distance was measured in three independent experiments. Results are given as mean \pm SD $(n=3)$. ${ }^{*} P<0.05$, NS = not significant, compared with the untreated control (lower panel). Representative images are shown (upper panel; original magnification, $\times 150)$. (B) The Boyden chamber assay was also performed to evaluate cell migration. BV-2 microglial cells $\left(5 \times 10^{4}\right.$ cells/upper well) placed in the Boyden chambers were exposed to mouse PAl-1 protein ( 0 to $1000 \mathrm{ng} / \mathrm{ml})$, and then incubated at $37^{\circ} \mathrm{C}$ for 6 hours. Microglial cells that migrated through a membrane were stained and counted. Results are given as mean $\pm S D(n=3)$. ${ }^{*} P<0.01$; compared with the untreated control (lower panel). Representative images are also shown (upper panel; original magnification, $\times 100)$. (C) BV-2 microglial cells were treated with BSA (0 to $22 \mathrm{nmol} / \mathrm{l})$ or PAl-1 $(2.2 \mathrm{nmol} / \mathrm{l} ; 100 \mathrm{ng} / \mathrm{ml})$, followed by the wound-healing assay as described above. Results are given as mean \pm $\mathrm{SD}(n=3) .{ }^{*} P<0.05$, NS = not significant, compared with the untreated control. (D) BV-2 microglial cells were seeded at the density of $5.0 \times 10^{3}$ cells/well in $96-$ well plate. Cells were treated with a mouse PAl-1 protein $(100 \mathrm{ng} / \mathrm{ml})$ and incubated at $37^{\circ} \mathrm{C}$ for $12-72$ hours to evaluate cell proliferation. Proliferation curves are based on the 2,5-diphenyltetrazolium bromide (MTT) assay. Results represent the mean \pm SD $(n=3)$. Proliferation of PAl-1-treated cells (open circle) was compared with the untreated control (filled square). (E) The Boyden chamber assay was performed to evaluate primary microglial cell migration. Primary microglia cultures $\left(5 \times 10^{4}\right.$ cells/upper well) placed in the Boyden chambers were exposed to mouse PAl-1 protein $(100 \mathrm{ng} / \mathrm{ml})$, and then incubated at $37^{\circ} \mathrm{C}$ for 24 hours. Microglial cells that migrated through a membrane were stained and counted. Results are mean $\pm \mathrm{SD}(n=3)$. ${ }^{*} P<0.05$; compared with the untreated control (lower panel). Representative images are also shown (upper panel). (F) C6 glioma cells were seeded at the density of $8.0 \times 10^{4}$ cells/well in 96-well plate. Cells were treated with BSA (100 ng/ $\mathrm{ml})$ or PAl-1 $(100 \mathrm{ng} / \mathrm{ml})$, followed by the wound-healing assay as described above. Results are the mean $\pm \operatorname{SD}(n=3)$. * $P<0.05$; compared with the untreated control.

normalized to Ponceau S staining (Figure 1A). PAI-1 was barely detectable in the conditioned medium of unstimulated glial cell cultures, consistent with the LC-MS/MS data. Soluble proteins from conditioned medium were precipitated using TCA/acetone solution, and the precipitate was solubilized in a detergent-containing buffer. This method was used to detect the proteins of low abundance in LC-MS/MS and western blotting analyses. However,

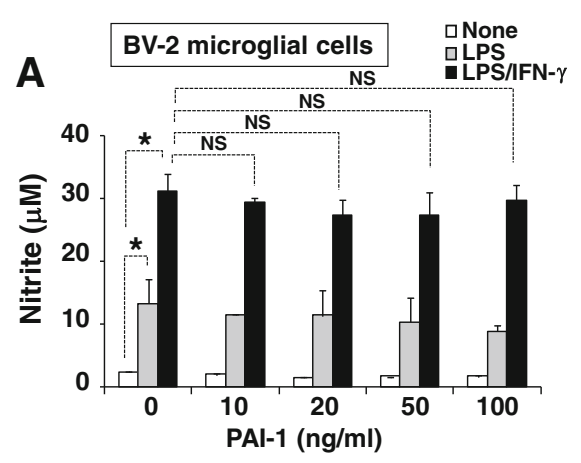

C
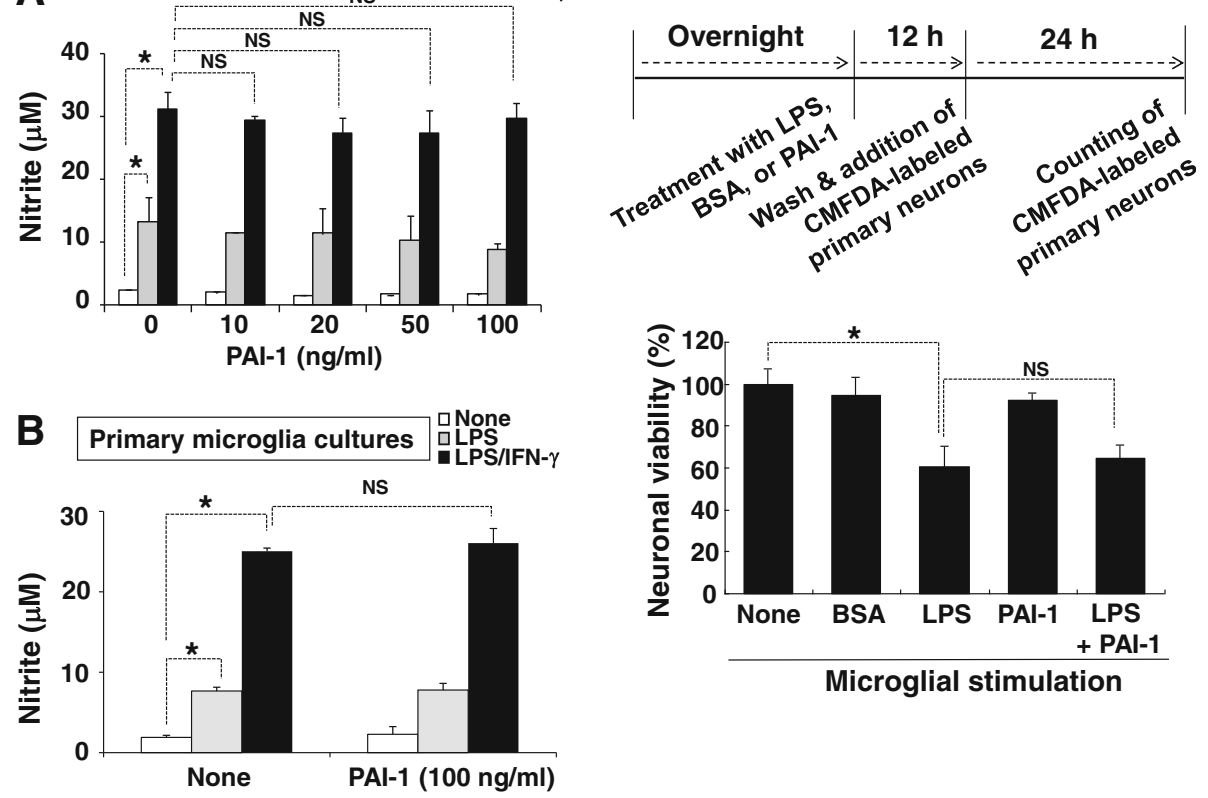

Figure 3 No significant effects of plasminogen activator inhibitor type 1 (PAI-1) on microglial nitric oxide (NO) production or neurotoxicity after lipopolysaccharide (LPS) or interferon (IFN)- $\gamma$ stimulation. (A) BV-2 microglial cells and (B) primary microglia cultures were treated with the indicated concentration of mouse PAl-1 protein, LPS $(100 \mathrm{ng} / \mathrm{ml})$, and IFN- $\gamma(50 \mathrm{U} / \mathrm{ml})$ for 24 hours. NO production was measured by the Griess reaction. Results are given as mean \pm SD $(n=3)$. ${ }^{*} P<0.01$, NS $=$ not significant. (C) Primary microglia cultures $\left(4.0 \times 10^{4}\right.$ cells/well) were treated for 12 hours with PAl-1 $(100 \mathrm{ng} / \mathrm{ml})$, BSA $(100 \mathrm{ng} / \mathrm{ml})$, or LPS $(100 \mathrm{ng} / \mathrm{ml})$ as indicated. Afterwards, primary microglial cells were cocultured with (upper panel) 5-chloromethyl-fluoresceindiacetate (CMFDA)-labeled primary neuron cultures for 24 hours (co-culture scheme). (Lower panel) CMFDA-positive neurons in the five randomly chosen microscopic fields per well were counted under an inverted microscope. Results are given as mean $\pm \mathrm{SD}(n=3) .{ }^{*} P<0.05, \mathrm{NS}=$ not significant. 


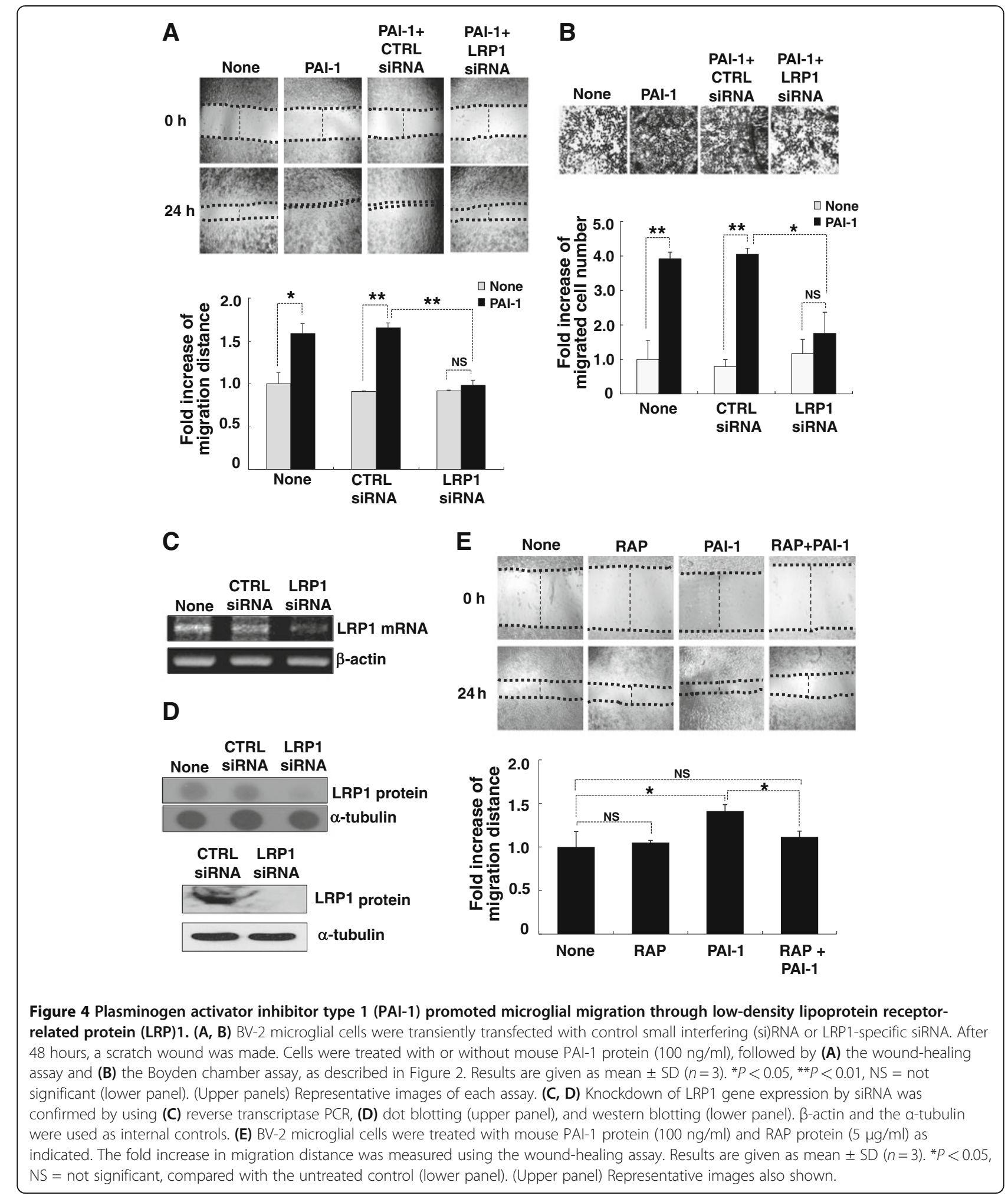

discrepancies in the protein precipitation and solubility may produce different protein profiles. For the direct quantification of PAI-1 levels in the conditioned medium and the identification of cellular source of PAI-1 secretion,
PAI-1-specific ELISA was performed for the separate glial cell cultures. LPS/IFN- $\gamma$ stimulation similarly increased the secretion of PAI-1 in the mixed glial cells, microglia, and astrocytes (Figure 1B), indicating that both microglia 
and astrocytes contribute to glial PAI-1 secretion. PAI-1 mRNA levels were also augmented by inflammatory stimulation in microglia and astrocytes. LPS, alone or in combination with IFN- $\gamma$, enhanced PAI-1 mRNA expression to varying degrees in glial cell lines and cultures (Figure 1C,D), but IFN- $\gamma$ alone did not have a significant effect. These results indicate that both microglia and astrocytes can be the major cellular sources of PAI-1 in the CNS under inflammatory conditions.

\section{Plasminogen activator inhibitor type 1 (PAI-1) promotes microglial migration, but not microglial proliferation or neurotoxic activation}

Having shown that both microglia and astrocytes secrete PAI-1 upon inflammatory stimulation, we next sought to determine how glia-derived PAI-1 influences proinflammatory phenotypes of microglia. We focused on microglial migration, nitric oxide (NO) production, and neurotoxicity, because it has been suggested that activated microglia are recruited to inflammatory sites and produce $\mathrm{NO}$ and other proinflammatory mediators, amplifying neuroinflammation and exerting neurotoxic effects. Effects of PAI-1 on microglial cell migration were first investigated using an in vitro wound-healing assay (Figure 2A) and Boyden chamber assay (Figure 2B, E). The mean plasma concentration of PAI-1 under physiological conditions is about 6 to $80 \mathrm{ng} / \mathrm{ml}$, but it can be increased in a number of pathological conditions [68]. In the migration assay, we used 1 to $1000 \mathrm{ng} / \mathrm{ml}$ of recombinant mouse PAI-1 protein, which is equivalent to 0.022 to $22.0 \mathrm{nmol} / \mathrm{l}$.

We found that PAI-1 promoted migration of BV-2 microglial cells in a dose-dependent manner. Significant effects on microglial migration were seen after treatment with $10 \mathrm{ng} / \mathrm{ml}(0.22 \mathrm{nmol} / \mathrm{l})$ or higher concentrations of 


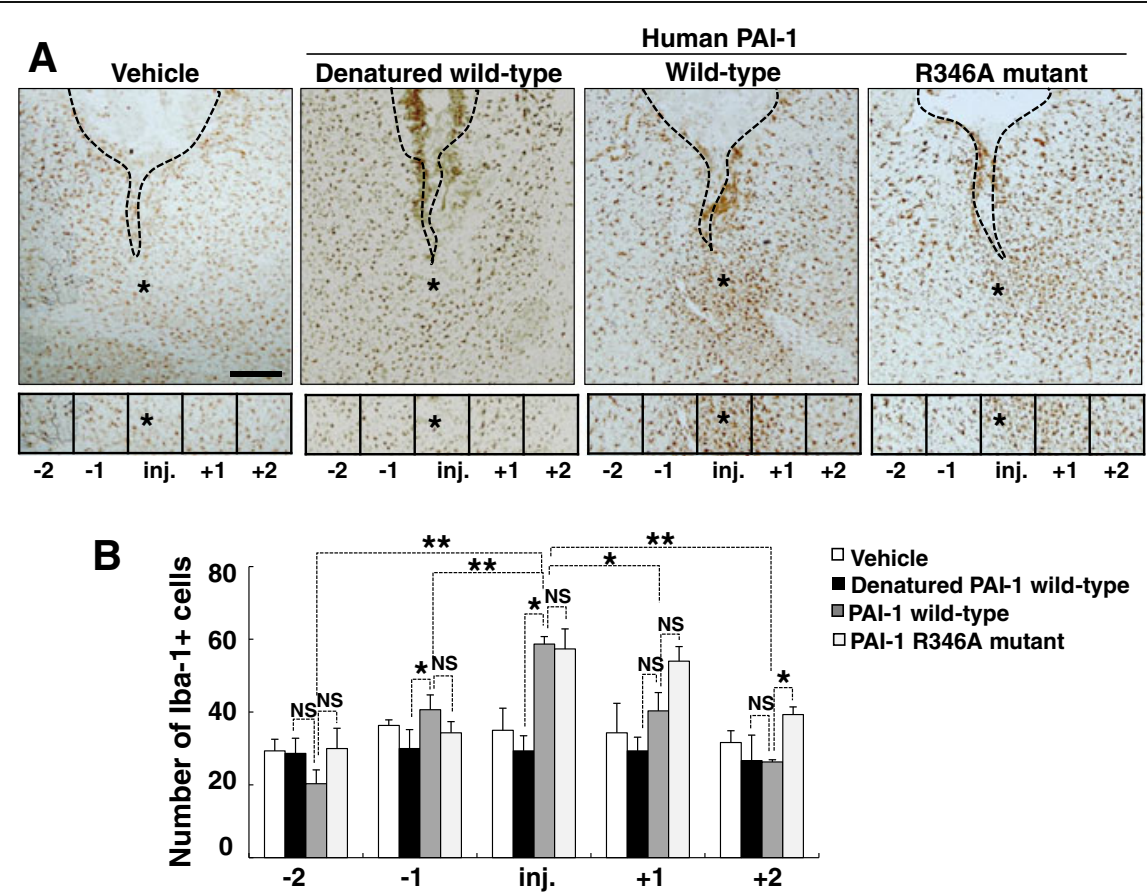

Figure 6 Plasminogen activator inhibitor type 1 (PAI-1) promoted microglial migration in vivo. (A, B) Microglial cells around the protein injection sites were stained with anti-lba-1 antibody at 48 hours after intrastriatal injection of vehicle (dialyzed elution buffer that was used for PAl-1 protein purification), denatured human PAl-1 wild-type, PAl-1 wild-type, or PAl-1 R346A mutant protein (1 $\mu$ l; $1.5 \mu \mathrm{g} / \mu \mathrm{l})$. Boxes indicate the $300 \times 300 \mu \mathrm{m}$ squares placed for cell counting. Immunohistochemistry results showed that Iba-1-positive cells were recruited into the injection site after injection of wild-type or R346 mutant PAl-1 protein. (B) Results are given as mean \pm SD from three animals and six independent sections per animal. ${ }^{*} P<0.05,{ }^{*} P<0.01$, NS = not significant. (A) Representative images (scale bar, $300 \mu m$ ). Asterisks indicate the injection sites (inj.). Guide cannula was stereotaxically located in the intrastriatal region (dotted line).

PAI-1 protein. Effects of BSA at the same molar concentration (0.022 to $22.0 \mathrm{nmol} / \mathrm{l})$ were compared as a control (Figure 2C). Sensitivity of microglia to PAI-1 was similar to that of rat and human smooth-muscle cells, MEF-1 fibroblasts, and HT1080 fibrosarcoma cells [35]. PAI-1 did not affect microglial proliferation (Figure 2D), indicating that the PAI-1 promotion of wound recovery was not related to microglial cell proliferation. PAI-1 also increased migration of primary microglia cultures (Figure 2E). These results, taken collectively, indicate that PAI-1 promotes the migration of microglia in culture. PAI-1 also increased C6 rat glioma cell migration by about 1.25 -fold over control (Figure 2F), suggesting that PAI-1 may exert similar effects on the dynamics of microglia and astrocytes. However, the effects of PAI-1 on astrocytes were not further investigated in this study.

Next, we determined whether PAI-1 could directly affect microglial activation. Because activated microglia release $\mathrm{NO}$ and other neurotoxic mediators, microglial NO production and neurotoxicity was measured to assess microglial activation. The recombinant mouse PAI-1 protein (10 to $100 \mathrm{ng} / \mathrm{ml}$ ) did not affect LPS-induced NO production (Figure $3 \mathrm{~A}, \mathrm{~B}$ ) or cell viability (data not shown) in BV-2 microglial cells or primary microglia cultures. PAI-1 did not influence microglial neurotoxicity in microglia-neuron cocultures (Figure 3C). LPS-stimulated microglia were neurotoxic in the co-culture, and this was not affected by PAI-1. These results indicate that PAI-1 does not affect microglial activation following LPS stimulation.

Plasminogen activator inhibitor type 1 (PAI-1) promotes microglial migration through the low-density lipoprotein receptor-related protein $1 /$ Janus kinase/signal transducer and activator of transcription-1 pathway

LRP1 has been previously implicated in the biological functions of PAI-1 [69,70]. LRP1 is a cell surface protein that has been shown to bind to a variety of ligands including apolipoprotein E, lipoprotein lipase, uPA, tPA, and PAI-1 [69]. To determine the role of LRP1 in the PAI-1-mediated microglial cell migration, we used LRP1 siRNA and RAP protein to inhibit LPR1 pathway. RAP has been shown to bind LRP1 and block its interactions with all known ligands including PAI-1. LRP1 gene silencing using siRNA abolished the PAI-1-promoted BV-2 microglial cell migration as determined by the woundhealing assay (Figure 4A) and the Boyden chamber assay (Figure 4B). Knockdown of LRP1 expression was shown by RT-PCR (Figure 4C), dot blotting analysis, and 

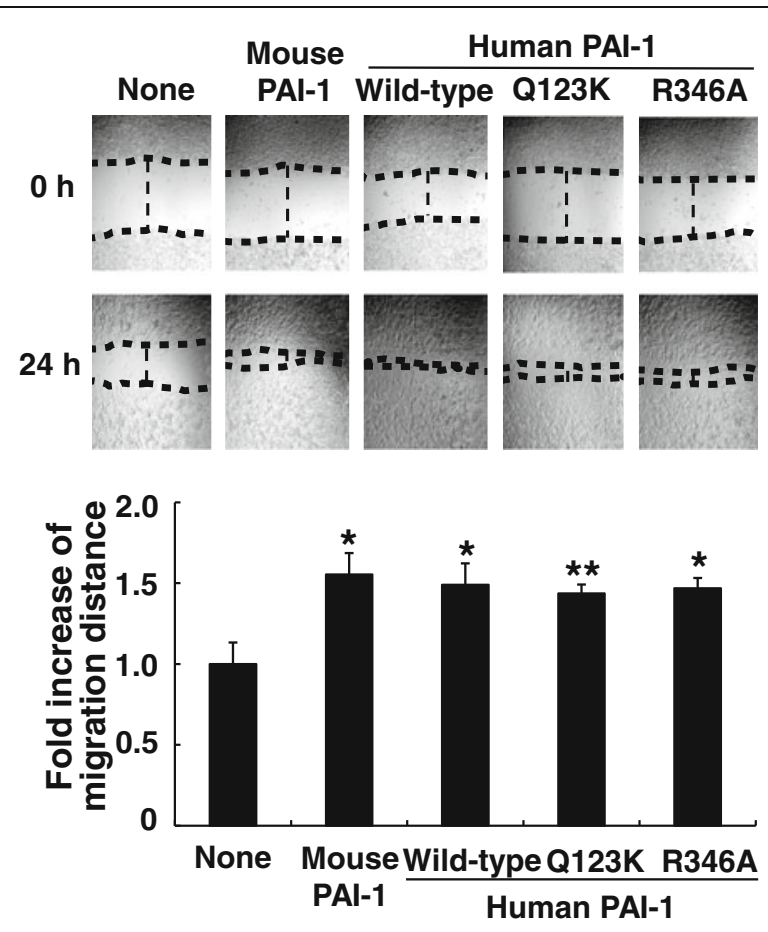

Figure 7 Plasminogen activator inhibitor type 1 (PAI-1)-induced microglial migration was independent of fibrinolysis or vitronectin binding. BV-2 microglial cells were treated with $100 \mathrm{ng} / \mathrm{ml}$ of mouse PAl-1, human wild-type PAl-1, or two variants (Q123K, R346A) of PAl-1 proteins, followed by a wound-healing assay as described in Figure 2. The wound recovery areas were visualized under an inverted microscope (upper panel), and the fold increase in migration distance was measured. Results are given as mean $\pm \mathrm{SD}(n=3)$. ${ }^{*} P<0.05,{ }^{* *} P<0.01$; compared with the untreated control (lower panel).

western blotting analysis using an LRP1-specific antibody (Figure 4D). The addition of RAP protein alone did not affect wound closure, but it completely blocked the migration-enhancing effect of PAI-1 in the woundhealing assay (Figure 4E). RAP was also able to block the effect of PAI-1 $(1-100 \mathrm{ng} / \mathrm{ml})$ in the Boyden chamber assay (data not shown). These results show that PAI-1 stimulates microglial migration via LRP1.

We next addressed intracellular signaling pathways associated with the PAI-1 activity. The JAK/STAT pathway has been previously implicated in cell migration [71,72], and a previous study [35] has shown that PAI-1 stimulates STAT1 activation in rat smooth-muscle cells. Thus, we evaluated the role of JAK/STAT1 pathway in the PAI-1-promoted microglial cell migration after LRP1 binding. PAI-1 alone induced STAT1 phosphorylation as determined by western blotting in BV-2 microglial cells (Figure 5A). IFN- $\gamma$ was used for comparison purposes [73]. LRP1 gene silencing diminished PAI-1-induced STAT1 phosphorylation (Figure 5B). LRP siRNA did not reduce IFN- $\gamma$-induced STAT1 phosphorylation, indicating that LRP siRNA did not cause cell toxicity (Figure 5C). Thus, LRP1 knockdown inhibited PAI-1induced STAT1 expression and activation. These results indicate that PAI-1 promotes microglial migration through the JAK/STAT1 pathway, and that LRP1 may reside in the upstream of the JAK/STAT1 signaling pathway in microglia. Indeed, the addition of AG490, a pharmacological inhibitor of JAK kinase, significantly attenuated the PAI-1-induced BV-2 microglial cell migration in the wound-healing assay (Figure 5D). These data indicate that PAI-1 enhances microglial cell migration via LRP1 and the JAK/ STAT1 pathway.

\section{Plasminogen activator inhibitor type 1 (PAI-1) is an inducer of microglial migration in vivo}

To determine whether PAI-1 promotes microglial motility in vivo, microglial accumulation was investigated after intrastriatal injection of human PAI-1 protein. Vehicle, denatured wild-type human PAI-1, wild-type human PAI-1, or the R346A human PAI-1 protein mutant were stereotaxically injected into the striatum of the mouse brain. Accumulation of microglia was immunohistochemically evaluated by counting Iba-1-positive cells around the injected area. At 48 hours after intrastriatal injection of wild-type human PAI-1 protein, there were large numbers of Iba-1-positive microglia accumulated around the PAI-1 injection site (Figure 6A,B). The R346A mutant protein, which is not capable of 


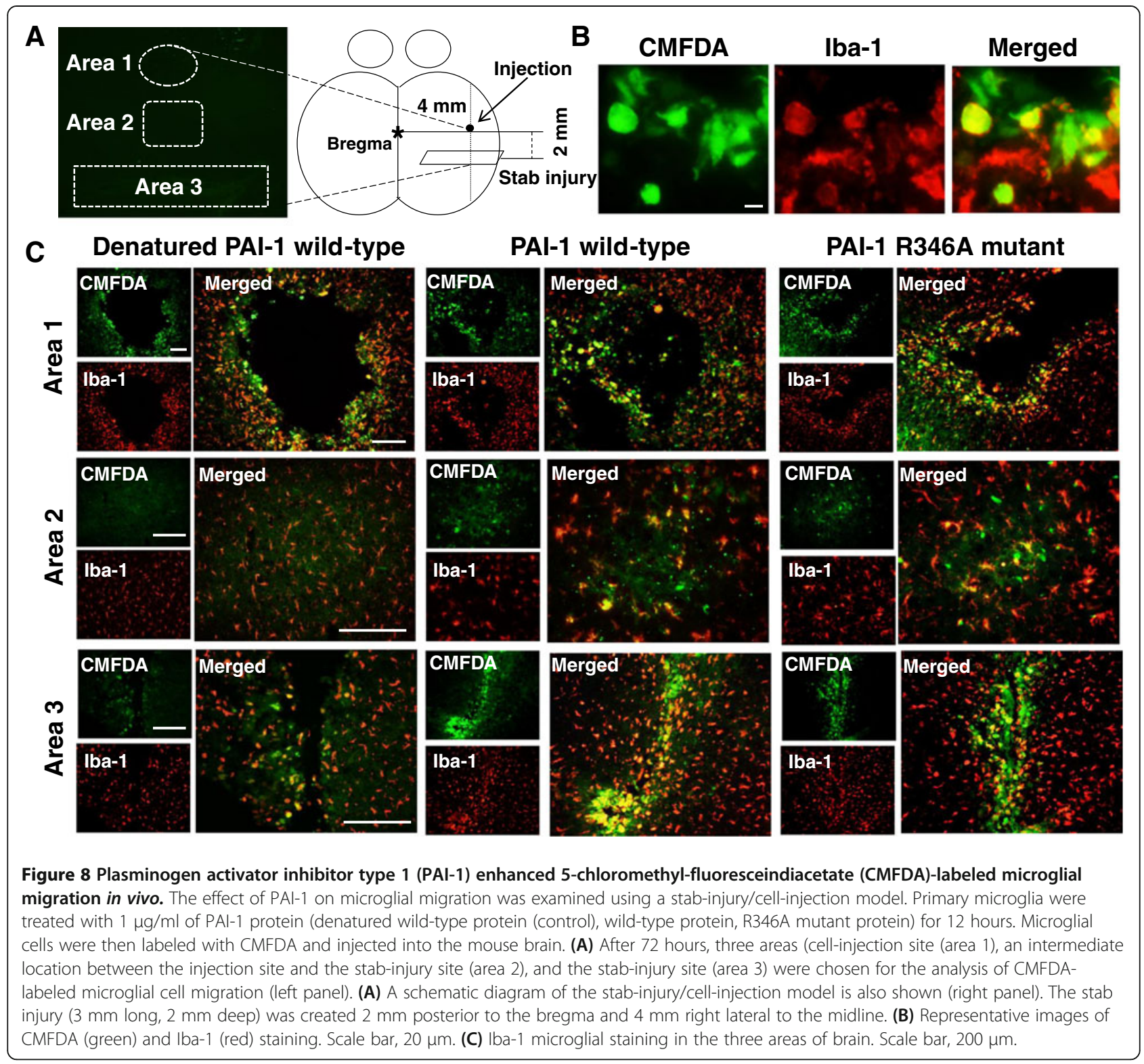

inhibiting PA, similarly induced microglial accumulation around the injection site. Denatured PAI-1 protein had no effect. Because the injection alone may cause tissue injuries, a basal level of microglial accumulation was seen after vehicle injection. Because PAI-1 did not induce microglial activation in vitro (Figure $3 \mathrm{~A}, \mathrm{~B}$ ), we suggest that the microglial accumulation seen in this experiment probably results from microglial recruitment rather than activation. The microglial migration-promoting activity of the R346A mutant protein was also seen in an in vitro migration assay, indicating that the PAI-1 effects are independent of the fibrinolysis system (Figure 7). Additionally, the Q123K mutant of human PAI-1 retained the migration-promoting activity in vitro, thereby suggesting that binding of PAI-1 to vitronectin may not be required for the activity. Recombinant human PAI-1 protein has been shown previously to be effective in mice [74]. Indeed, human and mouse PAI-1 protein exerted similar effects on the stimulation of microglial migration (Figure 7). To further exclude the possibility that microglial accumulation around the injection site is not due to cell activation or proliferation, another in vivo migration assay was performed using a stab-injury/cell-injection model, which has been previously used to determine glial cell migration in vivo [57,58]. In this method, fluorescently labeled microglial cells were injected into the cortex, and their migration toward the stab-injury site monitored. For this, primary microglial cells were treated with $1 \mu \mathrm{g} / \mathrm{ml}$ of PAI-1 protein (denatured wild-type protein as a control, 


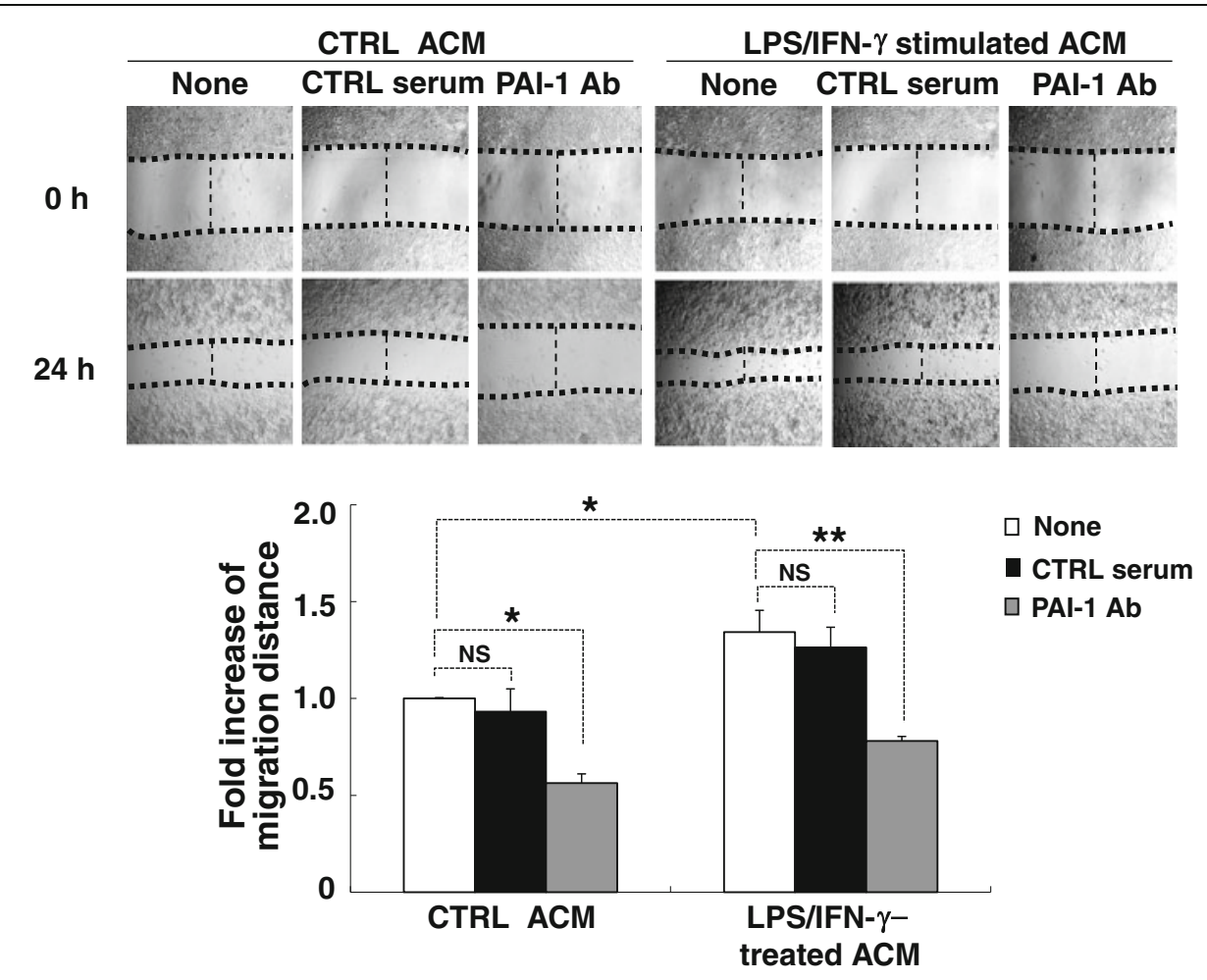

Figure 9 Astrocyte-derived plasminogen activator inhibitor type 1 (PAI-1) promoted the migration of microglia. Primary astrocytes were left untreated or treated with lipopolysaccharide (LPS; $100 \mathrm{ng} / \mathrm{ml})$ and interferon (IFN)- $\gamma(50 \mathrm{U} / \mathrm{ml})$ for 12 hours. Cells were then washed twice with PBS, and cultured in fresh DMEM for an additional 24 hours. The astrocyte-conditioned medium (ACM) was then collected. BV-2 microglial cells were treated for 24 hours with ACM in the presence or absence of PAl-1 neutralizing antibody (PAl-1 Ab; $2 \mu \mathrm{g} / \mathrm{ml}$ ), or normal rabbit serum $(2 \mathrm{\mu g} / \mathrm{ml})$ as control. Microglial migration was assessed by wound-healing assay as described in Figure 2 . At 0 and 24 hours, phase-contrast images of the wounds at three different locations were taken (upper panel, original magnification, $\times 150$ ), and then fold increase in migration distance from three independent experiments was measured (lower panel). Results are given as mean $\pm \mathrm{SD}(n=3) .{ }^{*} P<0.05,{ }^{*} P<0.01$, NS $=$ not significant.

wild-type protein, R346A mutant protein) for 12 hours, and the cells labeled with CMFDA. The CMFDA-labeled microglial cells were injected into the mouse brain, and then the stab injury was created. After 72 hours, three different areas (the cell-injection site, a location intermediate between the injection site and the stab-injury site, and the stab-injury site) were visible (Figure 8). Iba-1 immunostaining was also performed to identify microglial cells. Iba-1/CMFDA double-labeled cells were accumulated around the stab-injury site in the mouse brains after injection with PAI-1 wild-type or R346A mutant protein-treated microglia. Denatured PAI-1 protein had no effect. The results support the notion that PAI-1 promotes microglial migration in vivo.

\section{Plasminogen activator inhibitor type 1 (PAI-1) derived from astrocytes regulated microglial migration} In a series of experiments, we presented evidence that addition of exogenous PAI-1 protein promotes microglial migration both in vitro and in vivo. We next aimed to determine the role of endogenous PAI-1 protein in the regulation of microglial migration. Although microglia may contribute to PAI-1 secretion, astrocytes are thought to be the major cellular source of PAI-1 in the CNS in vivo $[23,43,75,76]$, because astrocytes outnumber microglia in the brain. Astroglial PAI-1 release was also detected in the current study (Figure 1B). Thus, we assessed the role of astrocyte-derived PAI-1 in the regulation of microglial migration using ACM and neutralizing antibodies against PAI-1. ACM was prepared from primary astrocyte cultures stimulated with a combination of LPS and IFN- $\gamma$. ACM promoted the migration of BV-2 microglial cells as determined by the woundhealing assay (Figure 9). To neutralize the PAI-1 activity in the ACM, a polyclonal anti-PAI-1 antibody was applied to BV-2 microglial cells together with ACM. Normal rabbit serum was used as a control. Abolishment of PAI-1 activity using anti- PAI-1 antibody significantly inhibited the effect of LPS/IFN- $\gamma$-stimulated ACM on microglial migration (Figure 9). PAI-1 neutralization also attenuated the effect of unstimulated ACM, indicating the presence of a low 

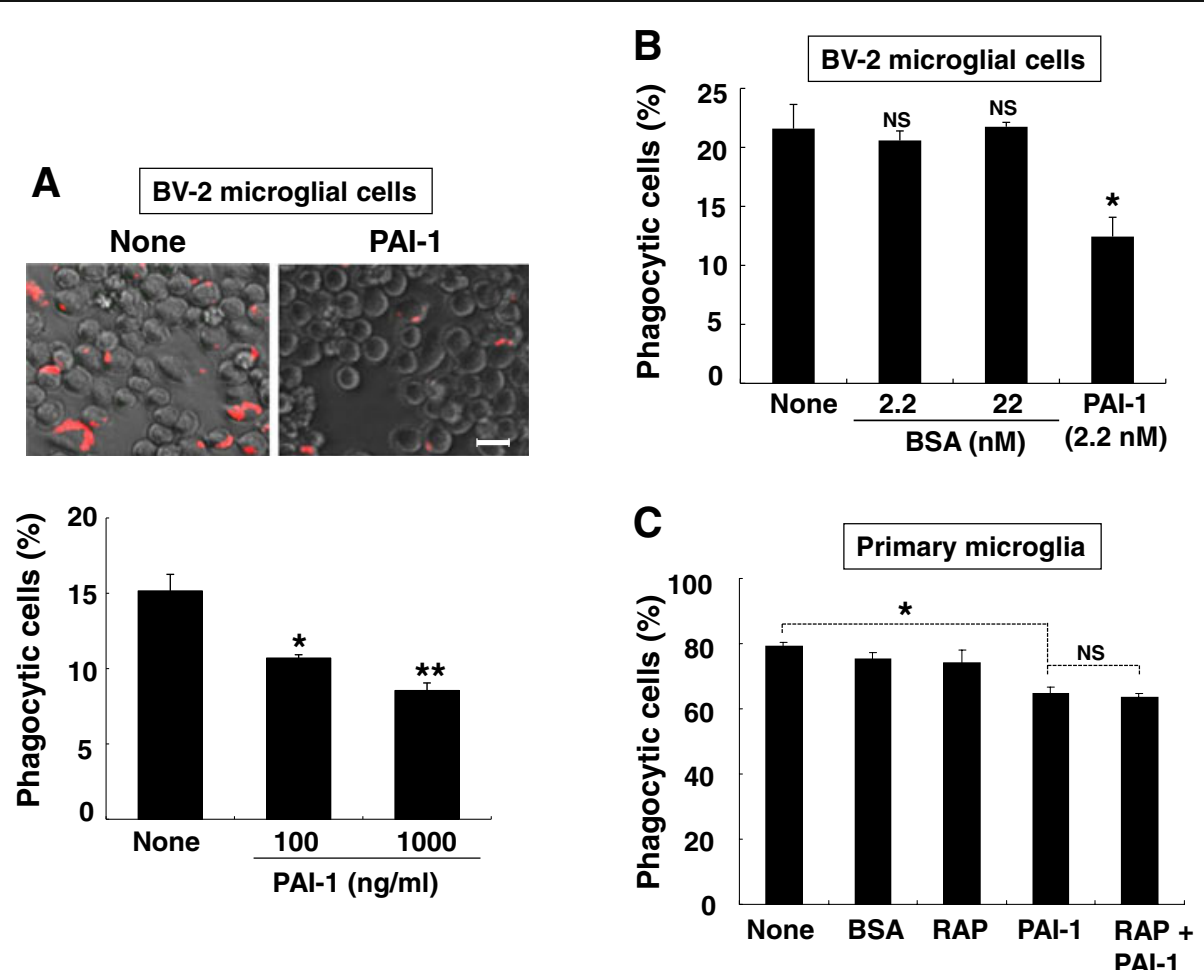

Figure 10 Plasminogen activator inhibitor type 1 (PAI-1) inhibited microglial phagocytosis of zymosan particles. (A) BV-2 microglial cells were treated with PAl-1 (100 or $1000 \mathrm{ng} / \mathrm{ml}$ ) for 1 hour and then incubated with zymosan particles conjugated with Alexa Fluor 594 (red) for 3 hours. Cells were washed five times with ice-cold PBS to remove bound particles. (A) Images at five different locations were taken and then the percentage of phagocytic cells was calculated based on the number of microglial cells that phagocytosed the zymosan particles (lower panel). (Upper panel) Representative images are shown. Results are given as mean \pm SD from three independent experiments. ${ }^{*} P<0.05$, ${ }^{* *} P<0.01$, different from untreated control. Scale bar $=20 \mu \mathrm{m}$. (B) BV-2 microglial cells were treated with BSA (2.2 or $22 \mathrm{nmol} / \mathrm{l})$ or PAl-1 (2.2 nmol/l; $100 \mathrm{ng} /$ $\mathrm{ml}$ ) for 1 hour and then incubated with zymosan particles for 3 hours, followed by the phagocytosis assay as described above. Results are given as mean \pm SD from three independent experiments. ${ }^{*} P<0.05, \mathrm{NS}=$ not significant, compared with the untreated control. Scale bar $=20 \mu \mathrm{m}$. (C) Primary microglia were treated with BSA $(100 \mathrm{ng} / \mathrm{ml})$, PAl-1 $(100 \mathrm{ng} / \mathrm{ml})$, or RAP protein $(5 \mu \mathrm{g} / \mathrm{ml})$ for 1 hour and then incubated with zymosan particles for 90 minutes. Microglial phagocytosis was assessed as described above. Results are given as mean \pm SD $(n=3)$. ${ }^{*} P<0.05$, NS $=$ not significant.

concentration of PAI-1 in the control ACM. These results further support that PAI-1 plays an important role in neuroinflammation by promoting microglial migration.

\section{Plasminogen activator inhibitor type 1 inhibited microglial phagocytosis of zymosan particles}

The effect of PAI-1 protein on the phagocytic activity of microglia was next investigated using zymosan particles as a prey. Zymosan particles are components of yeast cell wall, and served as a model for the phagocytosis of invading microbes [77]. The recombinant mouse PAI-1 protein inhibited the engulfment of zymosan particles in both BV-2 microglial cells and primary microglia cultures (Figure 10A, C). PAI-1 inhibited the microglial phagocytic activity in a dosedependent manner, as $1000 \mathrm{ng} / \mathrm{ml}$ of PAI-1 treatment produced greater inhibition than $100 \mathrm{ng} / \mathrm{ml}$ (Figure 10A). BSA $(2.2$ or $22.0 \mathrm{~mol} / \mathrm{l})$ did not inhibit the phagocytic activity of microglia (Figure 10B). To identify the role of LRP1 in the PAI-1 inhibition of microglial phagocytosis, primary microglial cultures were treated with PAI-1 in the presence of RAP peptide (Figure 10C). The addition of RAP did not affect the PAI-1 inhibition of microglial phagocytic activity, indicating that LRP1 is not involved in the PAI-1 reduction of microglial phagocytosis. TLR2, TLR6 and glucan receptor dectin-1 have been previously implicated in the recognition and phagocytosis of zymosan particles in either a cooperative or independent manner [78,79]. The mRNA (Figure 11A) and protein (Figure 11B) levels of TLR2 and TLR6 were markedly decreased after 6 hours of PAI-1 treatment, but there was no significant difference in dectin-1 mRNA or TLR9 protein levels (Figure 11A, B). Consistent with TLR2 mRNA/protein reduction, PAI-1 inhibited TLR2-mediated microglial activation as determined by NO production after stimulation with the TLR2 agonist LTA in primary microglia cultures (Figure 11C). 

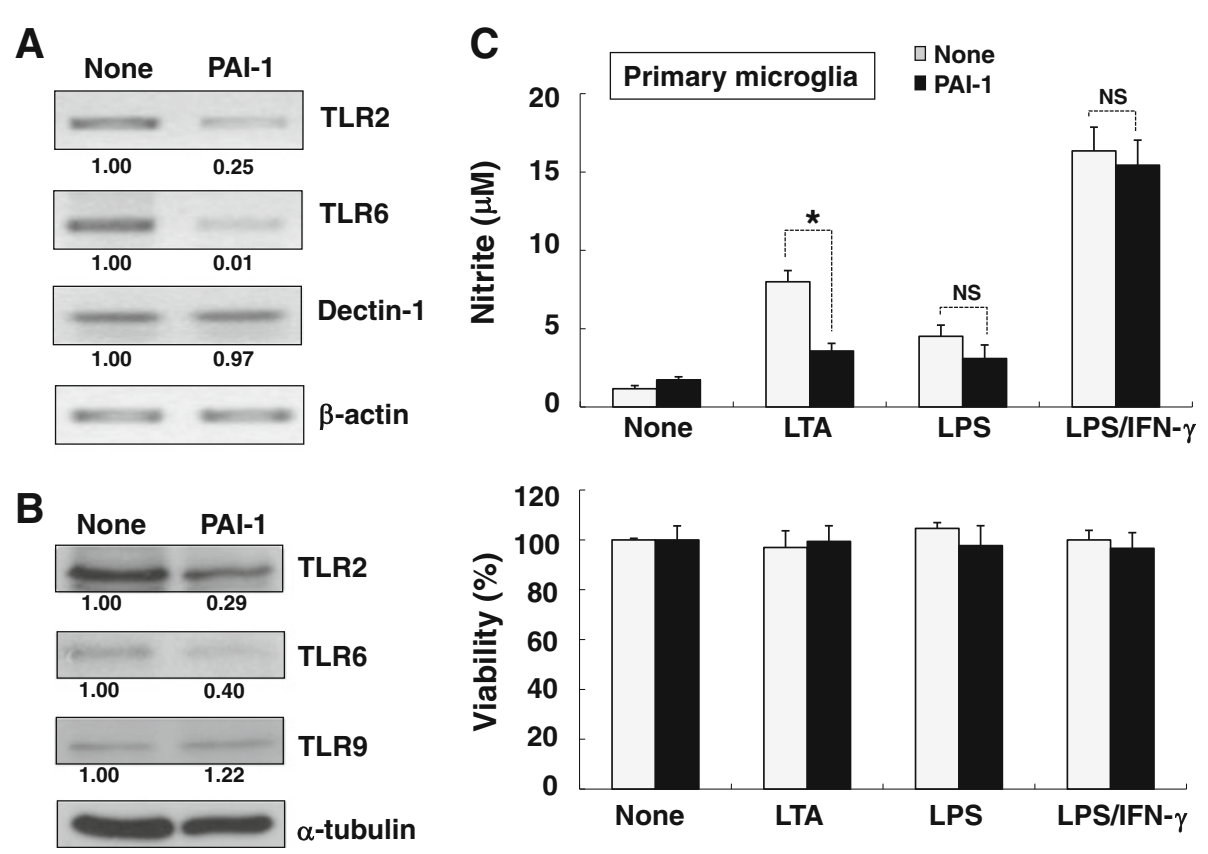

Figure 11 Plasminogen activator inhibitor type 1 (PAI-1) downregulated Toll-like receptor (TLR)2/6 expression and its signaling. (A) BV-2 microglial cells were treated with PAI-1 (100 ng/ml) for 5 hours. TLR2/TLR6 and dectin-1 gene expression was detected by reverse transcriptase PCR. $\beta$-actin was used as an internal control. (B) Alternatively, BV-2 microglial cells were treated with PAl-1 (100 ng/ml) for 24 hours. The levels of TLR2, TLR6, and TLR9 protein were then evaluated by western blotting analysis. a-tubulin was used as an internal control. Values indicate the results of densitometric analysis normalized to either $\beta$-actin or a-tubulin. (C) Primary microglia cultures were treated with mouse PAl-1 protein (100 ng/ml), lipopolysaccharide (LPS; $100 \mathrm{ng} / \mathrm{ml})$, interferon (IFN)- $-50 \mathrm{U} / \mathrm{ml}$ ), and lipoteichoic acid (LTA; $1 \mu \mathrm{gg} / \mathrm{ml})$ as indicated for 24 hours. (Upper panel) NO production was measured by a Griess reaction. (Lower panel) Cell viability was measured by 2,5-diphenyltetrazolium bromide (MTT) reduction assays, and the results expressed as the percentage of surviving cells over the control cells. Results are given as mean \pm $\mathrm{SD}(n=3) .{ }^{*} P<0.01, \mathrm{NS}=$ not significant.

To further define the inhibitory mechanism of PAI-1 in microglial phagocytosis, we used wild-type human PAI-1 protein, and the R346A and Q123K mutants of this protein. The wild-type protein and the R346A mutant (unable to inhibit PA) inhibited the engulfment of zymosan particles, whereas the Q123K mutant (with impaired vitronectin binding activity) did not have an inhibitory effect (Figure 12A). The addition of recombinant vitronectin protein to PAI-1treated microglial cells rescued the phagocytic activity (Figure 12B). We speculate that PAI-1 may inhibit the engulfment of zymosan particles by interfering with vitronectin/ITGB3 interaction. Vitronectin is a multifunctional molecule that binds to PAI-1, ITGB3, and bacteria [80]. To verify our hypothesis, the anti-TLR2 or anti-ITGB3 antibodies were applied to BV-2 microglial cells together with zymosan particles. Neutralization of either TLR2 or ITGB3 significantly inhibited microglial phagocytosis. The percentage inhibition by anti-TLR2 or anti-ITGB3 antibody was similar to that of recombinant PAI-1 (Figure 12C). These results suggest that PAI-1 may inhibit microglial phagocytic activity via TLR2 and ITGB3.

\section{Discussion}

Stimulated glial cells release various proinflammatory proteins such as cytokines, chemokines, and neurotoxic factors under pathological conditions [1,2]. These soluble proteins may play important roles in the progression of inflammatory diseases. Secretomic analysis of glia has been previously used to determine the secreted protein profiles during inflammatory responses $[3,4,6,51,65,66,81]$. In this study, we found that PAI-1 is one of the major proteins released by mixed glial cultures after inflammatory stimulation, and we provide evidence that PAI-1 is able to regulate microglial activation, migration, and phagocytosis under inflammatory condition.

PAI-1 is the primary inhibitor of uPA and tPA, which are involved in fibrinolysis [21,82]. PAI-1 also exerts numerous effects that are not dependent on PA inhibition $[27,28,83]$. PAI-1 levels are increased in brain diseases such as glioma, hypoxia, ischemic stroke, MS, and AD [38-41]. Astrocytes, but not microglia, are thought to be the major cellular source of PAI-1 in the CNS in vivo $[23,43,75,76]$. Our data suggest that microglia can also be a source of PAI-1 in the CNS. A recent study indicates that PAI-1 is also expressed in olfactory 

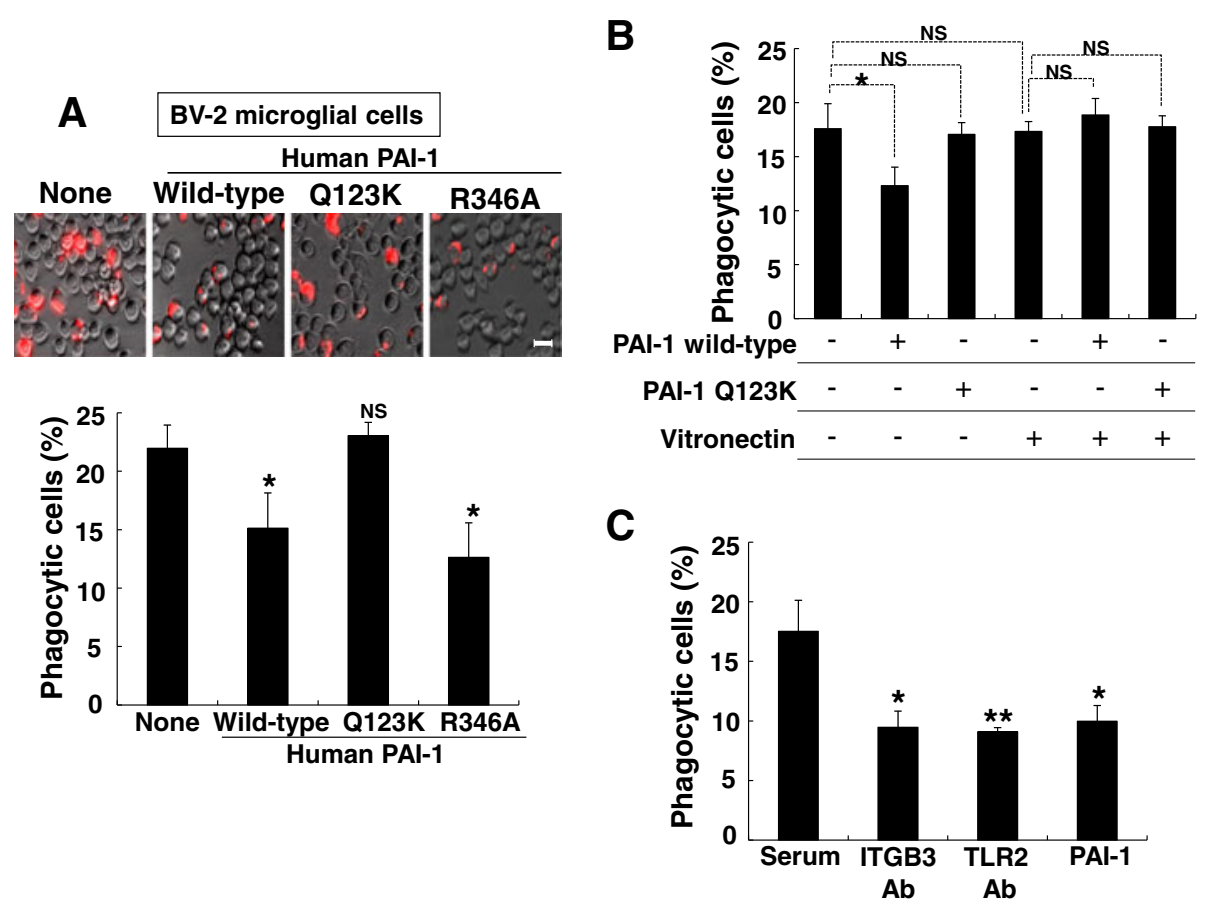

Figure 12 Plasminogen activator inhibitor type 1 (PAI-1) inhibited microglial phagocytosis in a vitronectin-dependent manner. (A) BV-2 microglial cells were treated with $100 \mathrm{ng} / \mathrm{ml}$ of human wild-type PAl-1, the Q123K variant, or the R346A variant for 1 hour, and then incubated for 3 hours with zymosan particles. (A) Microglial phagocytosis of fluorescent zymosan particles was assessed (lower panel) as described above. (Upper panel) Representative images are shown. Results are given as mean $\pm \mathrm{SD}(n=3) .{ }^{*} P<0.05$, NS $=$ not significantly different from untreated control. Scale bar $=20 \mu \mathrm{m}$. (B) BV-2 microglial cells were treated with human wild-type PAl-1 or the Q123K mutant (100 ng/ml) in the presence or absence of vitronectin $(1 \mu \mathrm{g} / \mathrm{ml})$ for 1 hour, and then incubated with zymosan particles for 3 hours, followed by phagocytosis assay. Results are given as mean $\pm \mathrm{SD}(n=3) .{ }^{*} P<0.05, \mathrm{NS}=$ not significant. (C) BV-2 microglial cells were incubated with zymosan particles in the presence or absence of Toll-like receptor (TLR)2 antibody (TLR2 Ab; $2 \mu \mathrm{g} / \mathrm{ml}$ ), integrin (ITG)B3 antibody (ITGB3 Ab; $2 \mu \mathrm{g} / \mathrm{ml}$ ), normal rabbit serum (2 $\mu \mathrm{g} / \mathrm{ml}$; negative control), or PAl-1 (100 ng/m; positive control). Microglial phagocytosis assay was performed. Results are given as mean \pm SD $(n=3)$. ${ }^{*} P<0.05,{ }^{*} P<0.01$, compared with normal serum.

ensheathing glia [44]. In the current study, PAI-1 mRNA expression was detected in primary astrocytes, primary microglia cultures, and cell lines of microglia or astrocyte origin (Figure 1C,D). PAI-1 protein secretion was increased in the LPS/IFN- $\gamma$-stimulated primary microglia and astrocyte cultures (Figure 1B). Thus, PAI-1 secreted by microglia or astrocytes may regulate microglial motility and phagocytic activity in an autocrine or paracrine manner under inflammatory conditions. Because microglial activation and ensuing neuroinflammation are key components of neurodegenerative diseases such as $\mathrm{AD}, \mathrm{PD}$, and MS, PAI-1 is likely to play an important role in regulating the inflammatory activation of microglia. Microglia-mediated neuroinflammation is characterized by a series of events, with a crucial step being the migration of microglia to the site of brain injury or inflammation [2,84], of which PAI-1 seems to be a central regulator. We found that PAI-1 modulates microglial activation after stimulation with TLR2 (Figure 11C), but not TLR4 (Figure 3A,B). TLR2 has been previously shown to exacerbate ischemic brain damage [85]. PAI-1 may play a regulatory role under pathological condition by suppressing TLR2 signaling. Indeed, PAI-1 has been shown to prevent apoptosis and even to protect against brain injury [42].

PAI-1 has been previously implicated in cell migration [86], and regulates cell migration through multiple mechanisms. PAI-1 has been shown to either enhance or suppress cell migration by interacting with various partner proteins such as UPA, tPA, LRP1, and vitronectin. PAI-1 suppresses cell migration by binding to vitronectin or uPA/uPAR. PAI-1 inhibited the motility of vascular smooth-muscle cells, human amnion WISH cells, and carcinoma cells via interaction with vitronectin [28-30,87], and vitronectin blocked the LRP1/PAI-1 pathway [33]. The PAI-1/uPA/ uPAR complex inhibited uPA-induced cell migration [34], whereas this complex mediated vitronectin-induced cell migration [88]. PAI-1 has been implicated in cancer invasion $[89,90]$ and angiogenesis [90]. PAI-1 stimulated the migration of monocytes and macrophages by interacting with LRP or tPA. By binding to LRP1, PAI-1 also enhanced the migration of rat and human smoothmuscle cells, mouse embryonic fibroblast-1, and 
fibrosarcoma cells (HT1080) [35]. PAI-1 also promoted the migration of lymphocytes and neutrophils into inflammatory sites [35,91,92]. Deficiency of PAI-1 abolished the migration of exudate macrophages [93]. The LRP/tPA/PAI-1 complex coordinated Mac-1dependent macrophage migration [37]. In the previous studies, the regulatory effects of PAI-1 on cell migration have been shown in various cell types such as monocytes and endothelial cells. However, it is not clear whether PAI-1 has positive or negative effects on glial cell migration in the CNS. The composition of the extracellular matrix (ECM) in the CNS is different from that of other tissue types. Laminin, fibronectin, and collagen are the major components of the ECM in most tissues, but are largely undetectable in the CNS [94-96]. Because the effect of PAI-1 heavily depends on ECM components such as vitronectin, PAI-1 may not necessarily play the same role in the CNS as in other peripheral tissues. In this study, we found that PAI-1 exerts positive effects on cell migration in the CNS. PAI-1 stimulated microglial migration through the LRP-1/JAK/STAT axis (Figure 4; Figure 5), which is consistent with previous reports in which STAT1 activation was found to be involved in PAI-1 induced cell migration in rat and human smooth-muscle cells and fibroblasts [35]. We used two different PAI1 mutants to further characterize the cell migrationpromoting activity of PAI-1. Vitronectin, in addition to PA, has been identified as a PAI-1-binding protein. The Q123K and R346A mutants, which, respectively, are unable to bind to vitronectin and unable to inhibit PA, retained the microglial migration-promoting activity (Figure 6, Figure 7, Figure 8). These results suggest that the microglia migration-regulating activity of PAI-1 we observed in the current study may not depend on either vitronectin binding or PA inhibition.

Recent reports indicated a novel role of PAI-1 in the regulation of phagocytosis of apoptotic or viable cells $[27,97]$. Our results show that PAI-1 inhibits microglial phagocytosis of zymosan particles (Figure $10 \mathrm{~A}, \mathrm{C}$ ). Human PAI-1 proteins (both wild-type and the R346A mutant) inhibited microglial phagocytic activity, whereas the Q123K mutant (unable to bind to vitronectin) did not. These results prompted us to speculate that PAI-1 inhibits microglial phagocytosis by binding to vitronectin, which is a functional partner of PAI-1. The PAI-1 /vitronectin complex interacts with the Arg-Gly-Asp motif of ITGB3, inhibits fibrinolysis, and modulates the pro-migratory effect of PAI-1 [28,30,32,33,87]. Vitronectin and integrin were previously shown to be required for TLR2-mediated activation of monocytes [98], and zymosan phagocytosis was dependent on TLR2 and TLR6 [99-101], while TLR2 deficiency attenuated bacterial clearance [102]. Our results suggest that PAI inhibits microglial phagocytosis by blocking the vitronectin/ ITGB3/TLR2 complex. Indeed, neutralization of ITGB3 or TLR2 inhibited microglial phagocytosis (Figure 12C). We also found that PAI-1 inhibited TLR2 and TLR6 expression (Figure 11A,B). Thus, PAI-1-mediated downregulation of TLR2 seems to reduce microglial phagocytic activity.

\section{Conclusions}

In this study, we found that PAI-1 released from microglia and astrocytes promotes microglial migration and inhibits phagocytosis in vitro. Some of our in vitro findings were supported by animal studies, in which PAI-1 was found to stimulate microglial recruitment into the injury site in mouse brain. PAI-1 promoted microglial migration via the LRP1/JAK/STAT1 axis, and inhibited microglial phagocytosis of zymosan particles. Extensive studies have been conducted for PAI-1 in cardiovascular diseases, obesity, and diabetes [103-107], but little is known about its role in inflammatory diseases of the brain. Our results suggest PAI-1 as a potential therapeutic target to control microglial migration and phagocytosis under pathological conditions in the CNS.

\begin{abstract}
Abbreviations
ACM: Astrocyte-conditioned medium; AD: Alzheimer's disease; BSA: Bovine serum albumin; CMFDA: 5-chloromethyl-fluoresceindiacetate; CNS: Central nervous system; DMEM: Dulbecco's modified Eagle's medium;

ECM: Extracellular matrix; FBS: fetal bovine serum; GFAP: Glial fibrillary acidic protein; Iba-1: Ionized calcium binding adaptor molecule 1; IFN- $\gamma$ : Interferon-

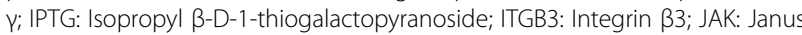
kinase; LC-MS/MS: Liquid chromatography and tandem mass spectrometry; LPS: Lipopolysaccharide; LRP1: Low-density lipoprotein receptor-related protein 1; LTA: Lipoteichoic acid; MS: Multiple sclerosis; Ni-NTA: Nickelnitrilotriacetic acid; NO: Nitric oxide; PAI-1: Plasminogen activator inhibitor type 1; PBS: Phosphate-buffered saline; PD: Parkinson's disease; RAP: Lowdensity lipoprotein receptor-associated protein; si: Small interfering; STAT1: Signal transducer and activator of transcription-1; tPA: Tissue type plasminogen activators; uPA: Urokinase type plasminogen activators.
\end{abstract}

\section{Competing interests}

The authors declare that they have no competing interests.

\section{Acknowledgements}

We thank Prof. Hana Im at Sejong University (Seoul, Korea) for generously providing the wild-type human PAl-1 plasmid. This work was supported by Basic Science Research Program through the National Research Foundation (NRF) funded by the Ministry of Education, Science and Technology (MEST) of Korean government (number 2011-0028240, 2009-0078941) and Bio R\&D program through the NRF funded by the MEST (2008-04090).

\section{Author details}

'Department of Pharmacology, Brain Science \& Engineering Institute, CMRI, Kyungpook National University School of Medicine, 101 Dong-In, Daegu, Joong-gu 700-422, South Korea. ' School of Life Sciences and Biotechnology, Kyungpook National University, Daegu, South Korea. ${ }^{3}$ Department of Medicine, Samsung Medical Center, Sungkyunkwan University School of Medicine, Seoul, South Korea.

\section{Authors' contributions}

HJ performed the experiments, analyzed the data, and wrote the manuscript. JHK and JHK both participated in immunohistological investigations and analysis of the data. WHL and MSL participated in the study design and data interpretation. KS was the main investigator of this work, and was in charge 
of the study design, analysis and interpretation of results, and writing. All authors read and approved the final manuscript.

Received: 21 January 2012 Accepted: 29 June 2012

Published: 29 June 2012

\section{References}

1. Popovich PG, Longbrake EE: Can the immune system be harnessed to repair the CNS? Nat Rev Neurosci 2008, 9:481-493.

2. Streit WJ, Mrak RE, Griffin WS: Microglia and neuroinflammation: a pathological perspective. J Neuroinflammation 2004, 1:14.

3. Lafon-Cazal M, Adjali O, Galeotti N, Poncet J, Jouin P, Homburger V, Bockaert J, Marin P: Proteomic analysis of astrocytic secretion in the mouse. Comparison with the cerebrospinal fluid proteome. J Biol Chem 2003, 278:24438-24448.

4. Keene SD, Greco TM, Parastatidis I, Lee SH, Hughes EG, Balice-Gordon RJ, Speicher DW, Ischiropoulos H: Mass spectrometric and computational analysis of cytokine-induced alterations in the astrocyte secretome. Proteomics 2009, 9:768-782.

5. Moore NH, Costa LG, Shaffer SA, Goodlett DR, Guizzetti M: Shotgun proteomics implicates extracellular matrix proteins and protease systems in neuronal development induced by astrocyte cholinergic stimulation. J Neurochem 2009, 108:891-908.

6. Kim S, Ock J, Kim AK, Lee HW, Cho JY, Kim DR, Park JY, Suk K: Neurotoxicity of microglial cathepsin $D$ revealed by secretome analysis. J Neurochem 2007, 103:2640-2650.

7. Liu J, Hong Z, Ding J, Liu J, Zhang J, Chen S: Predominant release of lysosomal enzymes by newborn rat microglia after LPS treatment revealed by proteomic studies. J Proteome Res 2008, 7:2033-2049.

8. Block ML, Zecca L, Hong JS: Microglia-mediated neurotoxicity: uncovering the molecular mechanisms. Nat Rev Neurosci 2007, 8:57-69.

9. Garden GA, Moller T: Microglia biology in health and disease. $J$ Neuroimmune Pharmacol 2006, 1:127-137.

10. Graeber MB, Streit WJ: Microglia: biology and pathology. Acta Neuropathol 2010, 119:89-105.

11. Mallat M, Marin-Teva JL, Cheret C: Phagocytosis in the developing CNS: more than clearing the corpses. Curr Opin Neurobiol 2005, 15:101-107.

12. Woo MS, Park JS, Choi IY, Kim WK, Kim HS: Inhibition of MMP-3 or -9 suppresses lipopolysaccharide-induced expression of proinflammatory cytokines and iNOS in microglia. J Neurochem 2008, 106:770-780.

13. Magnus T, Chan A, Savill J, Toyka KV, Gold R: Phagocytotic removal of apoptotic, inflammatory lymphocytes in the central nervous system by microglia and its functional implications. J Neuroimmunol 2002, 130:1-9.

14. Orr CF, Rowe DB, Halliday GM: An inflammatory review of Parkinson's disease. Prog Neurobiol 2002, 68:325-340.

15. Perry VH, Nicoll JA, Holmes C: Microglia in neurodegenerative disease. Nat Rev Neurol 2010, 6:193-201.

16. Wersinger $C$, Sidhu A: An inflammatory pathomechanism for Parkinson's disease? Curr Med Chem 2006, 13:591-602.

17. Eikelenboom P, Bate C, Van Gool WA, Hoozemans JJ, Rozemuller JM, Veerhuis R, Williams A: Neuroinflammation in Alzheimer's disease and prion disease. Glia 2002, 40:232-239.

18. Glass CK, Saijo K, Winner B, Marchetto MC, Gage FH: Mechanisms underlying inflammation in neurodegeneration. Cell 2010, 140:918-934.

19. McGeer PL, McGeer EG: Glial reactions in Parkinson's disease. Mov Disord 2008, 23:474-483.

20. Stence N, Waite M, Dailey ME: Dynamics of microglial activation: a confocal time-lapse analysis in hippocampal slices. Glia 2001, 33:256-266.

21. $\mathrm{Ha} \mathrm{H}, \mathrm{Oh}$ EY, Lee HB: The role of plasminogen activator inhibitor 1 in renal and cardiovascular diseases. Nat Rev Nephrol 2009, 5:203-211.

22. Gabriel C, Ali C, Lesne S, Fernandez-Monreal M, Docagne F, Plawinski L, Mackenzie ET, Buisson A, Vivien D: Transforming growth factor alphainduced expression of type 1 plasminogen activator inhibitor in astrocytes rescues neurons from excitotoxicity. FASEB J 2003, 17:277-279.

23. Hultman K, Blomstrand F, Nilsson M, Wilhelmsson U, Malmgren K, Pekny M, Kousted T, Jern C, Tjarnlund-Wolf A: Expression of plasminogen activator inhibitor-1 and protease nexin-1 in human astrocytes: Response to injury-related factors. J Neurosci Res 2010, 88:2441-2449.

24. Myohanen $H$, Vaheri $A$ : Regulation and interactions in the activation of cell-associated plasminogen. Cell Mol Life Sci 2004, 61:2840-2858.
25. Pepper MS, Rosnoblet C, Di Sanza C, Kruithof EK: Synergistic induction of tPA by vascular endothelial growth factor and basic fibroblast growth factor and localization of t-PA to Weibel-Palade bodies in bovine microvascular endothelial cells. Thromb Haemost 2001, 86:702-709.

26. Czekay RP, Aertgeerts K, Curriden SA, Loskutoff DJ: Plasminogen activator inhibitor-1 detaches cells from extracellular matrices by inactivating integrins. J Cell Biol 2003, 160:781-791.

27. Park YJ, Liu G, Lorne EF, Zhao X, Wang J, Tsuruta Y, Zmijewski J, Abraham E: PAl-1 inhibits neutrophil efferocytosis. Proc Natl Acad Sci U S A 2008, 105:11784-11789.

28. Stefansson S, Lawrence DA: The serpin PAl-1 inhibits cell migration by blocking integrin alpha V beta 3 binding to vitronectin. Nature 1996, 383:441-443.

29. Deng G, Curriden SA, Wang S, Rosenberg S, Loskutoff DJ: Is plasminogen activator inhibitor-1 the molecular switch that governs urokinase receptor-mediated cell adhesion and release? J Cell Biol 1996, 134:1563-1571.

30. Kjoller L, Kanse SM, Kirkegaard T, Rodenburg KW, Ronne E, Goodman SL, Preissner KT, Ossowski L, Andreasen PA: Plasminogen activator inhibitor-1 represses integrin- and vitronectin-mediated cell migration independently of its function as an inhibitor of plasminogen activation. Exp Cell Res 1997, 232:420-429.

31. Kirchheimer JC, Binder BR, Remold HG: Matrix-bound plasminogen activator inhibitor type 1 inhibits the invasion of human monocytes into interstitial tissue. J Immunol 1990, 145:1518-1522.

32. Zhou A, Huntington JA, Pannu NS, Carrell RW, Read RJ: How vitronectin binds PAl-1 to modulate fibrinolysis and cell migration. Nat Struct Biol 2003, 10:541-544.

33. Kamikubo Y, Neels JG, Degryse B: Vitronectin inhibits plasminogen activator inhibitor-1-induced signalling and chemotaxis by blocking plasminogen activator inhibitor-1 binding to the low-density lipoprotein receptor-related protein. Int J Biochem Cell Biol 2009, 41:578-585.

34. Degryse B, Sier CF, Resnati M, Conese M, Blasi F: PAl-1 inhibits urokinaseinduced chemotaxis by internalizing the urokinase receptor. FEBS Lett 2001, 505:249-254.

35. Degryse B, Neels JG, Czekay RP, Aertgeerts K, Kamikubo Y, Loskutoff DJ: The low density lipoprotein receptor-related protein is a motogenic receptor for plasminogen activator inhibitor-1. J Biol Chem 2004, 279:22595-22604.

36. Harrison $\mathrm{BH}$ : Intercellular junctions in the developing mammalian thymus. Anat Histol Embryol 1977, 6:325-331.

37. Cao C, Lawrence DA, Li Y, Von Arnim CA, Herz J, Su EJ, Makarova A, Hyman BT, Strickland DK, Zhang L: Endocytic receptor LRP together with TPA and PAI-1 coordinates Mac-1-dependent macrophage migration. EMBO J 2006, 25:1860-1870.

38. Gveric D, Herrera B, Petzold A, Lawrence DA, Cuzner ML: Impaired fibrinolysis in multiple sclerosis: a role for tissue plasminogen activator inhibitors. Brain 2003, 126:1590-1598.

39. Jacobsen JS, Comery TA, Martone RL, Elokdah H, Crandall DL, Oganesian A, Aschmies S, Kirksey Y, Gonzales C, Xu J, Zhou H, Atchison K, Wagner E, Zaleska MM, Das I, Arias RL, Bard J, Riddell D, Gardell SJ, Abou-Gharbia M, Robichaud A, Magolda R, Vlasuk GP, Bjornsson T, Reinhart PH, Pangalos MN: Enhanced clearance of Abeta in brain by sustaining the plasmin proteolysis cascade. Proc Natl Acad Sci U S A 2008, 105:8754-8759.

40. Muracciole X, Romain S, Dufour H, Palmari J, Chinot O, Ouafik L, Grisoli F, Branger DF, Martin PM: PAI-1 and EGFR expression in adult glioma tumors: toward a molecular prognostic classification. Int J Radiat Oncol Biol Phys 2002, 52:592-598.

41. Nagai N, Suzuki Y, Van Hoef B, Lijnen HR, Collen D: Effects of plasminogen activator inhibitor-1 on ischemic brain injury in permanent and thrombotic middle cerebral artery occlusion models in mice. J Thromb Haemost 2005, 3:1379-1384.

42. Yang D, Nemkul N, Shereen A, Jone A, Dunn RS, Lawrence DA, Lindquist D, Kuan CY: Therapeutic administration of plasminogen activator inhibitor-1 prevents hypoxic-ischemic brain injury in newborns. J Neurosci 2009, 29:8669-8674.

43. Docagne F, Nicole O, Gabriel C, Fernandez-Monreal M, Lesne S, Ali C, Plawinski L, Carmeliet P, Mackenzie ET, Buisson A, Vivien D: Smad3-dependent induction of plasminogen activator inhibitor-1 in astrocytes mediates neuroprotective activity of transforming growth factor-beta 1 against NMDA-induced necrosis. Mol Cell Neurosci 2002, 21:634-644. 
44. Simon D, Martin-Bermejo MJ, Gallego-Hernandez MT, Pastrana E, GarciaEscudero V, Garcia-Gomez A, Lim F, Diaz-Nido J, Avila J, Moreno-Flores MT: Expression of plasminogen activator inhibitor-1 by olfactory ensheathing glia promotes axonal regeneration. Glia 2011, 59:1458-1471.

45. Xu Z, Balsara RD, Gorlatova NV, Lawrence DA, Castellino FJ, Ploplis VA: Conservation of critical functional domains in murine plasminogen activator inhibitor-1. J Biol Chem 2004, 279:17914-17920.

46. Lawrence DA, Berkenpas MB, Palaniappan S, Ginsburg D: Localization of vitronectin binding domain in plasminogen activator inhibitor-1. J Biol Chem 1994, 269:15223-15228.

47. Lee $\mathrm{HJ}, \mathrm{Im} \mathrm{H}$ : Purification of recombinant plasminogen activator inhibitor- 1 in the active conformation by refolding from inclusion bodies. Protein Expr Purif 2003, 31:99-107.

48. Blasi E, Barluzzi R, Bocchini V, Mazzolla R, Bistoni F: Immortalization of murine microglial cells by a v-raf/v-myc carrying retrovirus. $J$ Neuroimmunol 1990, 27:229-237.

49. Bocchini V, Mazzolla R, Barluzzi R, Blasi E, Sick P, Kettenmann H: An immortalized cell line expresses properties of activated microglial cells. J Neurosci Res 1992, 31:616-621.

50. McCarthy KD, de Vellis J: Preparation of separate astroglial and oligodendroglial cell cultures from rat cerebral tissue. J Cell Biol 1980, 85:890-902.

51. Jeon H, Lee S, Lee WH, Suk K: Analysis of glial secretome: the long pentraxin PTX3 modulates phagocytic activity of microglia. $J$ Neuroimmunol 2010, 229:63-72.

52. Saura J, Tusell JM, Serratosa J: High-yield isolation of murine microglia by mild trypsinization. Glia 2003, 44:183-189.

53. Ock J, Kim S, Yi KY, Kim NJ, Han HS, Cho JY, Suk K: A novel antineuroinflammatory pyridylimidazole compound KR-31360. Biochem Pharmacol 2009, 87:2578-2590.

54. Yin GN, Lee HW, Cho JY, Suk K: Neuronal pentraxin receptor in cerebrospinal fluid as a potential biomarker for neurodegenerative diseases. Brain Res 2009, 1265:158-170.

55. Liang CC, Park AY, Guan JL: In vitro scratch assay: a convenient and inexpensive method for analysis of cell migration in vitro. Nat Protoc 2007, 2:329-333

56. Bassi R, Giussani P, Anelli V, Colleoni T, Pedrazzi M, Patrone M, Viani P, Sparatore B, Melloni E, Riboni L: HMGB1 as an autocrine stimulus in human T98G glioblastoma cells: role in cell growth and migration. Neurooncol 2008, 87:23-33.

57. Auguste Kl, Jin S, Uchida K, Yan D, Manley GT, Papadopoulos MC, Verkman AS: Greatly impaired migration of implanted aquaporin-4-deficient astroglial cells in mouse brain toward a site of injury. FASEB $J 2007$, 21:108-116.

58. Ryu JK, Cho T, Choi HB, Wang YT, McLarnon JG: Microglial VEGF receptor response is an integral chemotactic component in Alzheimer's disease pathology. J Neurosci 2009, 29:3-13.

59. Wada M, Yoshimi K, Higo N, Ren YR, Mochizuki H, Mizuno Y, Kitazawa S: Statistical parametric mapping of immunopositive cell density. Neurosci Res 2006, 56:96-102.

60. Kagan JC, Roy CR: Legionella phagosomes intercept vesicular traffic from endoplasmic reticulum exit sites. Nat Cell Biol 2002, 4:945-954

61. Park D, Han CZ, Elliott MR, Kinchen JM, Trampont PC, Das S, Collins S, Lysiak J, Hoehn KL, Ravichandran KS: Continued clearance of apoptotic cells critically depends on the phagocyte Ucp2 protein. Nature 2011, 477:220-224

62. Goodridge HS, Reyes CN, Becker CA, Katsumoto TR, Ma J, Wolf AJ, Bose N, Chan AS, Magee AS, Danielson ME, Weiss A, Vasilakos JP, Underhill DM: Activation of the innate immune receptor Dectin-1 upon formation of a 'phagocytic synapse'. Nature 2011, 472:471-475.

63. Greenbaum D, Luscombe NM, Jansen R, Qian J, Gerstein M: Interrelating different types of genomic data, from proteome to secretome: 'oming in on function. Genome Res 2001, 11:1463-1468.

64. Grimmond SM, Miranda KC, Yuan Z, Davis MJ, Hume DA, Yagi K, Tominaga N, Bono H, Hayashizaki Y, Okazaki Y, Teasdale RD: The mouse secretome: functional classification of the proteins secreted into the extracellular environment. Genome Res 2003, 13:1350-1359.

65. Dowell JA, Johnson JA, Li L: Identification of astrocyte secreted proteins with a combination of shotgun proteomics and bioinformatics. $J$ Proteome Res 2009, 8:4135-4143.
66. Delcourt N, Jouin P, Poncet J, Demey E, Mauger E, Bockaert J, Marin P, Galeotti N: Difference in mass analysis using labeled lysines (DIMAL-K): a new, efficient proteomic quantification method applied to the analysis of astrocytic secretomes. Mol Cell Proteomics 2005, 4:1085-1094.

67. Suk K: Combined analysis of the glia secretome and the CSF proteome: neuroinflammation and novel biomarkers. Expert Rev Proteomics 2010, 7:263-274.

68. Liu RM: Oxidative stress, plasminogen activator inhibitor 1, and lung fibrosis. Antioxid Redox Signal 2008, 10:303-319.

69. Lillis AP, Van Duyn LB, Murphy-Ullrich JE, Strickland DK: LDL receptorrelated protein 1: unique tissue-specific functions revealed by selective gene knockout studies. Physiol Rev 2008, 88:887-918.

70. Binder BR, Christ G, Gruber F, Grubic N, Hufnagl P, Krebs M, Mihaly J, Prager GW: Plasminogen activator inhibitor 1: physiological and pathophysiological roles. News Physiol Sci 2002, 17:56-61.

71. Aaronson DS, Horvath CM: A road map for those who don't know JAKSTAT. Science 2002, 296:1653-1655.

72. Rawlings JS, Rosler KM, Harrison DA: The JAK/STAT signaling pathway. Cell Sci 2004, 117:1281-1283.

73. Kovarik P, Stoiber D, Novy M, Decker T: Stat1 combines signals derived from IFN-gamma and LPS receptors during macrophage activation. EMBO J 1998, 17:3660-3668.

74. Huang Y, Border WA, Yu L, Zhang J, Lawrence DA, Noble NA: A PAI-1 mutant, PAI-1R, slows progression of diabetic nephropathy. J Am Soc Nephrol 2008, 19:329-338.

75. Cunningham O, Campion S, Perry VH, Murray C, Sidenius N, Docagne F, Cunningham C: Microglia and the urokinase plasminogen activator receptor/uPA system in innate brain inflammation. Glia 2009, 57:1802-1814.

76. Kim JW, Lee SH, Ko HM, Kwon KJ, Cho KS, Choi CS, Park JH, Kim HY, Lee J, Han SH, Ignarro LJ, Cheong JH, Kim WK, Shin CY: Biphasic regulation of tissue plasminogen activator activity in ischemic rat brain and in cultured neural cells: essential role of astrocyte-derived plasminogen activator inhibitor-1. Neurochem Int 2011, 58:423-433.

77. Aderem A, Underhill DM: Mechanisms of phagocytosis in macrophages. Annu Rev Immunol 1999, 17:593-623.

78. Chan GC, Chan WK, Sze DM: The effects of beta-glucan on human immune and cancer cells. J Hematol Oncol 2009, 2:25.

79. Brown GD, Gordon S: Immune recognition. A new receptor for betaglucans. Nature 2001, 413:36-37.

80. Scibelli A, Roperto S, Manna L, Pavone LM, Tafuri S, Della Morte R, Staiano $\mathrm{N}$ : Engagement of integrins as a cellular route of invasion by bacterial pathogens. Vet J 2007, 173:482-491.

81. Schleef RR, Loskutoff DJ: Fibrinolytic system of vascular endothelial cells. Role of plasminogen activator inhibitors. Haemostasis 1988, 18:328-341.

82. Brown NJ: Therapeutic potential of plasminogen activator inhibitor-1 inhibitors. Ther Adv Cardiovasc Dis 2010, 4:315-324

83. Vial D, McKeown-Longo PJ: PAl1 stimulates assembly of the fibronectin matrix in osteosarcoma cells through crosstalk between the alphavbeta5 and alpha5beta1 integrins. J Cell Sci 2008, 121:1661-1670.

84. Kreutzberg GW: Microglia: a sensor for pathological events in the CNS. Trends Neurosci 1996, 19:312-318.

85. Lehnardt S, Lehmann S, Kaul D, Tschimmel K, Hoffmann O, Cho S, Krueger C, Nitsch R, Meisel A, Weber JR: Toll-like receptor 2 mediates CNS injury in focal cerebral ischemia. J Neuroimmunol 2007, 190:28-33.

86. Dellas C, Loskutoff DJ: Historical analysis of PAI-1 from its discovery to its potential role in cell motility and disease. Thromb Haemost 2005, 93:631640.

87. Garg N, Goyal N, Strawn TL, Wu J, Mann KM, Lawrence DA, Fay WP: Plasminogen activator inhibitor-1 and vitronectin expression level and stoichiometry regulate vascular smooth muscle cell migration through physiological collagen matrices. J Thromb Haemost 2010, 8:1847-1854.

88. Stahl A, Mueller BM: Melanoma cell migration on vitronectin: regulation by components of the plasminogen activation system. Int J Cancer 1997 71:116-122.

89. Bajou K, Noel A, Gerard RD, Masson V, Brunner N, Holst-Hansen C, Skobe M, Fusenig NE, Carmeliet P, Collen D, Foidart JM: Absence of host plasminogen activator inhibitor 1 prevents cancer invasion and vascularization. Nat Med 1998, 4:923-928. 
90. Bajou K, Maillard C, Jost M, Lijnen RH, Gils A, Declerck P, Carmeliet P, Foidart $\mathrm{JM}$, Noel A: Host-derived plasminogen activator inhibitor-1 (PAl-1) concentration is critical for in vivo tumoral angiogenesis and growth. Oncogene 2004, 23:6986-6990.

91. Marshall LJ, Ramdin LS, Brooks T, DPhil PC, Shute JK: Plasminogen activator inhibitor-1 supports IL-8-mediated neutrophil transendothelial migration by inhibition of the constitutive shedding of endothelial IL-8/heparan sulfate/syndecan-1 complexes. J Immunol 2003, 171:2057-2065.

92. Arndt PG, Young SK, Worthen GS: Regulation of lipopolysaccharideinduced lung inflammation by plasminogen activator Inhibitor-1 through a JNK-mediated pathway. J Immunol 2005, 175:4049-4059.

93. Osterholzer JJ, Christensen PJ, Lama V, Horowitz JC, Hattori N, Subbotina N, Cunningham A, Lin Y, Murdock BJ, Morey RE, Olszewski MA, Lawrence DA, Simon RH, Sisson TH: PAl-1 promotes the accumulation of exudate macrophages and worsens pulmonary fibrosis following type II alveolar epithelial cell injury. J Pathol 2012, doi:10.1002/path.3992.

94. Sanes JR: Extracellular matrix molecules that influence neural development. Annu Rev Neurosci 1989, 12:491-516.

95. Sobel RA: The extracellular matrix in multiple sclerosis lesions. J Neuropathol Exp Neurol 1998, 57:205-217.

96. Lo EH, Wang X, Cuzner ML: Extracellular proteolysis in brain injury and inflammation: role for plasminogen activators and matrix metalloproteinases. J Neurosci Res 2002, 69:1-9.

97. Zmijewski JW, Bae HB, Deshane JS, Peterson CB, Chaplin DD, Abraham E: Inhibition of neutrophil apoptosis by PAl-1. Am J Physiol Lung Cell Mol Physiol 2011, 301:L247-L254.

98. Gerold G, Ajaj KA, Bienert M, Laws HJ, Zychlinsky A, de Diego JL: A Toll-like receptor 2-integrin beta3 complex senses bacterial lipopeptides via vitronectin. Nat Immunol 2008, 9:761-768.

99. Ozinsky A, Underhill DM, Fontenot JD, Haijar AM, Smith KD, Wilson CB, Schroeder $L$, Aderem A: The repertoire for pattern recognition of pathogens by the innate immune system is defined by cooperation between toll-like receptors. Proc Natl Acad Sci U S A 2000, 97:13766-13771.

100. Frasnelli ME, Tarussio D, Chobaz-Peclat V, Busso N, So A: TLR2 modulates inflammation in zymosan-induced arthritis in mice. Arthritis Res Ther 2005, 7:R370-R379.

101. Underhill DM, Ozinsky A, Hajjar AM, Stevens A, Wilson CB, Bassetti M, Aderem A: The Toll-like receptor 2 is recruited to macrophage phagosomes and discriminates between pathogens. Nature 1999, 401:811-815.

102. Letiembre M, Echchannaoui H, Bachmann P, Ferracin F, Nieto C, Espinosa M, Landmann R: Toll-like receptor 2 deficiency delays pneumococcal phagocytosis and impairs oxidative killing by granulocytes. Infect Immun 2005, 73:8397-8401.

103. De Taeye B, Smith LH, Vaughan DE: Plasminogen activator inhibitor-1: a common denominator in obesity, diabetes and cardiovascular disease. Curr Opin Pharmacol 2005, 5:149-154.

104. Skurk T, Hauner H: Obesity and impaired fibrinolysis: role of adipose production of plasminogen activator inhibitor-1. Int J Obes Relat Metab Disord 2004, 28:1357-1364.

105. Schneider DJ: Abnormalities of coagulation, platelet function, and fibrinolysis associated with syndromes of insulin resistance. Coron Artery Dis 2005, 16:473-476.

106. Esposito K, Giugliano D: The metabolic syndrome and inflammation: association or causation? Nutr Metab Cardiovasc Dis 2004, 14:228-232.

107. Monteiro R, Azevedo I: Chronic inflammation in obesity and the metabolic syndrome. Mediators Inflamm 2010, 2010:289645.

doi:10.1186/1742-2094-9-149

Cite this article as: Jeon et al:: Plasminogen activator inhibitor type 1 regulates microglial motility and phagocytic activity. Journal of Neuroinflammation 2012 9:149.

\section{Submit your next manuscript to BioMed Central and take full advantage of:}

- Convenient online submission

- Thorough peer review

- No space constraints or color figure charges

- Immediate publication on acceptance

- Inclusion in PubMed, CAS, Scopus and Google Scholar

- Research which is freely available for redistribution

Submit your manuscript at www.biomedcentral.com/submit 